\title{
Influence of temperature and particle size on the single and mixed atmosphere gasification of biomass char with $\mathrm{H}_{2} \mathrm{O}$ and $\mathrm{CO}_{2}$
}

\author{
C. Guizani *, F.J. Escudero Sanz *, S. Salvador \\ RAPSODEE, Mines Albi, Route de Teillet, 81013 Albi CT, Cedex 09, France
}

\begin{abstract}
A B S T R A C T
The paper focuses on the gasification of biomass chars in $\mathrm{H}_{2} \mathrm{O}, \mathrm{CO}_{2}$ and their mixtures. The first part is dedicated to the study of the influence of particle size and temperature in single atmosphere gasification experiments. The Thiele approach was successfully applied to assess the extent of diffusional limitations. We also studied the mixed atmosphere gasification of $0.2 \mathrm{~mm}$ chars at various temperatures and found that the char reactivity is fairly rep resented by an additive law at relatively low temperatures while it is lower than the sum of the individual con tributions for high temperature cases. Similarly, we assessed the effect of particle size for mixed atmosphere experiments and found that an additive law was representative of the experimental reactivities for particle sizes from 0.2 to $13 \mathrm{~mm}$. The present work provides useful and worthy information on the char gasification re activity in conditions close to practical operating ones encountered in biomass gasifiers.
\end{abstract}

Keywords:

Biomass char

$\mathrm{CO}_{2}$

$\mathrm{H}_{2} \mathrm{O}$

Reactivity

Mixed atmospheres

Thiele modulus

\section{Introduction}

Char gasification is an important step the global operation of bio mass gasification. Indeed, when a biomass particle is gasified, it dries first, pyrolysis in second lieu, resulting in emission of gas species and formation of a solid char containing mainly carbon with some oxygen, hydrogen and mineral species in a far lesser amount. The produced char reacts with the gasification medium resulting in the production of additional gaseous species mainly composed by $\mathrm{CO}$ and $\mathrm{H}_{2}$. The gasi fication reaction is the limiting step in the global gasification reaction and is of major importance in the sizing of gasifiers [1]. Inside a gasifier, the solid char can react with various gasifying agents such as $\mathrm{O}_{2}, \mathrm{H}_{2} \mathrm{O}$, $\mathrm{CO}_{2}$ and $\mathrm{H}_{2}$. The gasifying agents have two origins: either they are pro vided by an external supply into the gasifier or are produced inside the gasifier by the drying and pyrolysis reactions. In most practical situa tions, the char reacts with a mixture of these species following the reac tion of char combustion and gasification:

Char combustion

Partial combustion : $\mathrm{C}+1 / 2 \mathrm{O}_{2} \rightarrow \mathrm{CO}(-111 \mathrm{~kJ} / \mathrm{mol})$
Complete combustion : $\mathrm{C}+\mathrm{O}_{2} \rightarrow \mathrm{CO}_{2}(-394 \mathrm{~kJ} / \mathrm{mol})$

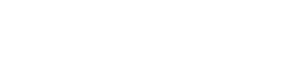

* Corresponding authors.

(C. Guizani), javier.escuderosanz@mines-albi.fr (F.J. Escudero Sanz), sylvain.salvador@mines-albi.fr (S. Salvador).

\section{Char gasification}

Steam gasification : $\mathrm{C}+\mathrm{H}_{2} \mathrm{O} \rightarrow \mathrm{CO}+\mathrm{H}_{2}(+131 \mathrm{~kJ} / \mathrm{mol})$
Boudouard reaction : $\mathrm{C}+\mathrm{CO}_{2} \rightarrow 2 \mathrm{CO}(+173 \mathrm{~kJ} / \mathrm{mol})$

Hydrogen gasification(Methanisation) : $\mathrm{C}+2 \mathrm{H}_{2} \rightarrow \mathrm{CH}_{4}(-75 \mathrm{~kJ} / \mathrm{mol})$.

Huge literature exists on biomass char combustion and gasification with $\mathrm{O}_{2}, \mathrm{H}_{2} \mathrm{O}$ and $\mathrm{CO}_{2}$. The reader can refer to Di Blasi's review on com bustion and gasification rates of biomass chars [2]. A wide range of gas ification kinetic data of various char biomasses is reported. On the contrary, few studies deal with the gasification of biomass char in com plex atmospheres containing more than one gasifying agent in partic ular $\mathrm{CO}_{2}+\mathrm{H}_{2} \mathrm{O}$ while it is of practical interest to study the effects of mixing the gases on the char gasification reaction, as it is representative of practical situation in gasifiers. For instance, inside a fixed bed gasifier, a char particle can be gasified simultaneously by more than a gasifying agent. It can also react at first with a gas " $\mathrm{A}$ ", for instance $\mathrm{CO}_{2}$, and then reacts with another one, a gas " $\mathrm{B}$ ", $\mathrm{H}_{2} \mathrm{O}$ for example, and vice versa. It's therefore of interest to study the mixed atmosphere gasifica tion of chars as well as the mutual effects of gases on the char reactive properties, providing thus worthy information for near practical condi tions encountered in such processes.

In mixed atmosphere gasification reactions, $\mathrm{H}_{2} \mathrm{O}$ and $\mathrm{CO}_{2}$ can react separately (passive cooperation or additivity), the reactivity in a mixed atmosphere of $\mathrm{CO}_{2}$ and $\mathrm{H}_{2} \mathrm{O}$ can be therefore expressed as the sum of 
the single reactivities. The two gases can also compete and react on shared active sites (Competition). The reactivity in mixed atmosphere of $\mathrm{CO}_{2}$ and $\mathrm{H}_{2} \mathrm{O}$ is therefore lower than the sum of the single reactivities. The third case, there can be synergy between the two gases (synergy or active cooperation) and the char reactivity in mixed atmosphere gasifi cation experiments is higher than the sum of the single reactivities.

An overview on the literature focusing on complex atmosphere gas ification of biomass chars shows for instance that Groeneveld and Van Swaaij [3] studied the wood char gasification reaction in a mixture of $\mathrm{H}_{2} \mathrm{O}$ and $\mathrm{CO}_{2}$. The authors proposed a $n$th order model for wood char gas ification in a mixed atmosphere of $\mathrm{H}_{2} \mathrm{O}$ and $\mathrm{CO}_{2}$. The two reactions were assumed to have the same activation energy and the global reaction rate was dependant on the sum of the partial pressures of $\mathrm{H}_{2} \mathrm{O}$ and $\mathrm{CO}_{2}$.

Maria Barrio and co workers [4] performed experiments of wood char gasification in steam carbon dioxide mixtures. The authors found that the carbon conversion is mainly due to steam gasification mean while the carbon dioxide, which is less reactive, has potentially another role when it is injected as a co reactant with steam but in any case would inhibit the gasification reaction.

In 2008, Tagutchu et al. [5] observed a synergy between $\mathrm{H}_{2} \mathrm{O}$ and $\mathrm{CO}_{2}$ when mixed together as a gasifying agent. They found that the char re activity in mixed atmospheres of $\mathrm{CO}_{2}+\mathrm{H}_{2} \mathrm{O}$ was higher than the sum of the single reactivities and concluded to synergy effects between the two gases. They proposed a model based on the work of Robert and Harris [6] in which the $\mathrm{H}_{2} \mathrm{O}$ and $\mathrm{CO}_{2}$ react on separate active sites. As suggested in [5], the authors think that $\mathrm{CO}_{2}$ creates additional micro porosity and enhances the access of $\mathrm{H}_{2} \mathrm{O}$ to the active sites.

The gasification of a large variety of biomass samples was investigat ed in a TG apparatus with a heating rate of $10^{\circ} \mathrm{C} /$ min up to $1000^{\circ} \mathrm{C}$ using steam, carbon dioxide or a mixture of both reactants as a gasification me dium [7]. The authors observed that regardless of the biomass type, in troducing $\mathrm{CO}_{2}$ with a minimum amount of $30 \%$ next to steam into the flow stream resulted in a complete char burnout with a light mineral film remaining in the crucible, whereas a black char residue remains when using only steam as a gasification medium. In a complementary study, the same authors reported several facts related to $\mathrm{CO}_{2}$ addition as a co gasifying medium with steam such as the enhanced char micro porosity [8].

Susana Nilsson et al. studied the gasification of dried sewage sludge (DSS) chars in a pilot fluidized bed reactor under $\mathrm{CO}_{2}, \mathrm{H}_{2} \mathrm{O}$ and their mixtures [9]. The experiments were performed in a temperature range of $800900{ }^{\circ} \mathrm{C}$ and a gas partial pressure of 0.10 .3 bar. The authors demonstrated that the DSS char reactivity in mixed atmospheres of $\mathrm{H}_{2} \mathrm{O}$ and $\mathrm{CO}_{2}$ can be expressed as the sum of single atmosphere gasifica tion reactivities.

Susana Nilsson et al. studied the gasification reactivity of olive tree pruning [10] in the same fluidized bed apparatus. The experiments were done in a temperature range of $760900{ }^{\circ} \mathrm{C}$ in mixtures of $\mathrm{CO}_{2}$, $\mathrm{H}_{2} \mathrm{O}, \mathrm{H}_{2}, \mathrm{CO}$ and $\mathrm{N}_{2}$. The authors determined the reaction kinetic con stants respectively for the $\mathrm{CO}_{2}$ and the $\mathrm{H}_{2} \mathrm{O}$ gasification reactions. After wards, they performed gasification experiments in mixtures of $\mathrm{H}_{2} \mathrm{O}$ and $\mathrm{CO}_{2}$ and found that their experimental results are correctly described by summing the two single rates.
In our previous work on the gasification of HHR chars and LHR chars at $900{ }^{\circ} \mathrm{C}$, we found that regardless of the pyrolysis conditions, and for various $\mathrm{CO}_{2}+\mathrm{H}_{2} \mathrm{O}$ concentrations in the gasification medium, the char reactivity in mixed atmospheres can be fairly described by sum ming the single reactivities obtained respectively under $\mathrm{H}_{2} \mathrm{O}$ and $\mathrm{CO}_{2}$ [11].

The main results on biomass char gasification in mixed atmospheres of $\mathrm{CO}_{2}$ and $\mathrm{H}_{2} \mathrm{O}$ as discussed before are summarized in Table 1.

Studies on mixed atmosphere gasification of chars originating from coal or lignite are more numerous than those performed on biomass chars. It is of great interest to refer to them as the chars have several common features, but without forgetting that they are not identical to avoid hasty conclusions and non reliable comparisons. For instance, Liliedahl and Sjöström [12] studied the gasification of finely ground lig nite char samples of $0.51 \mathrm{~g}$ in a thermo balance at atmospheric and el evated pressures, at temperatures between 750 and $850{ }^{\circ} \mathrm{C}$, using a number of $\mathrm{CO} \mathrm{CO}_{2} \mathrm{H}_{2} \mathrm{O}$ Ar mixtures. The authors found that the mixed atmosphere char gasification reactivity can be modelled follow ing a common active site reaction mechanism.

Roberts and Harris [6] performed a comparative study on the gasifi cation of a charcoal in single atmospheres of $\mathrm{H}_{2} \mathrm{O}$ and $\mathrm{CO}_{2}$ and in a mix ture of the two gases. In a mixed atmosphere, the char conversion rate decreased comparatively with that obtained in a pure steam gasification medium which led the authors to conclude the inhibiting effect of $\mathrm{CO}_{2}$ on the steam gasification reaction. They proposed the model below as suming that there is a competition between steam and carbon dioxide for the same surface reaction sites. The authors made the assumption that the $\mathrm{CO}_{2}$ carbon gasification reaction rate is so low that the reduc tion in the available surface area by adsorbed $\mathrm{C}(\mathrm{O})$ species from the $\mathrm{CO}_{2}$ reaction is likely behind the decrease in steam gasification reaction upon addition of $\mathrm{CO}_{2}$. These conclusions are nonetheless hasty as they were drawn for a $010 \%$ char conversion level. Carbon dioxide seems to inhibit the steam carbon reaction in the earlier stage of gasification, yet there is a lack of evidence to conclude the permanent inhibiting ef fect throughout the gasification reaction.

Everson et al. [13] also investigated the effect of a mixture of carbon dioxide and steam on the gasification of char coals. Firstly, they conduct gasification experiments in binary gas mixtures $\left(\mathrm{H}_{2} \mathrm{O}+\mathrm{H}_{2}\right.$ and $\left.\mathrm{CO}_{2}+\mathrm{CO}\right)$ for the determination of the rate constants. The gasification reaction was best described with the assumption that the reactions oc curred on separate sites.

More recently, Huang et al. [14] carried the same gasification exper iments as Everson et al. They determined the different gasification con stants by studying the char gasification with the binary gas mixtures $\mathrm{H}_{2} \mathrm{O}+\mathrm{H}_{2}$ and $\mathrm{CO}_{2}+\mathrm{CO}$. Experiments with multi component gasifying mixtures $\left(\mathrm{H}_{2} \mathrm{O}+\mathrm{H}_{2}+\mathrm{CO}_{2}+\mathrm{CO}\right)$ were also carried out showing results that fit well with the "separate reactive sites" reaction model given above. The comparison was based on the char reactivity at a conversion level of $50 \%$. The calculated predictions according to the model were very close to the experimental values.

The assumption of reaction on separate active sites was also held by Tay et al. [15] for coal char gasification. The authors performed gasifica tion experiments at $800^{\circ} \mathrm{C}$ with different gasification atmospheres $(15 \%$

Table 1

Literature review on biomass char gasification in mixed atmospheres of $\mathrm{CO}_{2}$ and $\mathrm{H}_{2} \mathrm{O}$.

\begin{tabular}{|c|c|c|c|}
\hline Reference & Char & Pyrolysis conditions & Mixed atmosphere mechanism \\
\hline [3] & Wood char $(4 \mathrm{~cm})$ & & Same activation energy and dependance on the sum of partial pressure \\
\hline [4] & Birch wood char $(45-63 \mu \mathrm{m})$ & $\begin{array}{l}\text { Slow pyrolysis } \\
24^{\circ} \mathrm{C} / \mathrm{min}\end{array}$ & Competition \\
\hline [5] & Pine wood char $(5.5 \mathrm{~mm})$ & Medium rate pyrolysis in a screw reactor at $60^{\circ} \mathrm{C} / \mathrm{s}$ & Synergy \\
\hline [7] & Various biomasses & Slow pyrolysis $10^{\circ} \mathrm{C} / \mathrm{min}$ & Synergy \\
\hline [9] & Dried sewage sludge char $(1.2 \mathrm{~mm})$ & Fast pyrolysis in FBR & Additivity \\
\hline [10] & Olive tree pruning char $(1.9 \mathrm{~mm})$ & Fast pyrolysis in FBR & Additivity \\
\hline [11] & Beech wood char $(1 \mathrm{~mm})$ & $\begin{array}{l}\text { Fast pyrolysis } 100^{\circ} \mathrm{C} / \mathrm{s} \\
\text { Slow pyrolysis } 5^{\circ} \mathrm{C} / \mathrm{min}\end{array}$ & Additivity \\
\hline
\end{tabular}


$\mathrm{H}_{2} \mathrm{O}$ balanced with $\mathrm{Ar} ; 4000$ ppm $\mathrm{O}_{2}$ balanced with $\mathrm{CO}_{2} ; 4000$ ppm O $\mathrm{O}_{2}$, $15 \% \mathrm{H}_{2} \mathrm{O}$ balanced with $\mathrm{CO}_{2}$ ) and gasification holding times. Char con version rate calculations show that the degree of char conversion during the gasification in an $\mathrm{O}_{2}+\mathrm{H}_{2} \mathrm{O}+\mathrm{CO}_{2}$ mixture was approximately equal to the sum of those during the gasification in $15 \% \mathrm{H}_{2} \mathrm{O}$ (balanced with argon) and in $\mathrm{O}_{2}+\mathrm{CO}_{2}$ mixture. They suggest that the additivity in char conversion means that $\mathrm{O}_{2}, \mathrm{H}_{2} \mathrm{O}$ and $\mathrm{CO}_{2}$ do not compete for the same active sites on the coal/char.

More recently, Chen et al. [16] investigated the effect of the pyrolysis conditions on the gasification reactivity of lignite chars in mixtures of $\mathrm{H}_{2} \mathrm{O}+\mathrm{CO}_{2}$. Two kinds of char were prepared from a lignite by fast py rolysis using a drop tube furnace and by slow pyrolysis using a fixed bed furnace at a temperature of $1273 \mathrm{~K}$. Char gasification reactions with $\mathrm{CO}_{2}$, $\mathrm{H}_{2} \mathrm{O}$ and their mixtures were performed in a thermogravimetric analyser (TGA) system. The gasification rate equations derived from TGA were afterwards validated by fluidized bed gasification experi ments. The authors found that both fast chars and slow chars were dense. The shrinking core model was able to predict gasification of both fast char and slow char, which means that the reaction occurs mainly in the external surface. The authors found that the char gasifica tion rate in the mixtures of $\mathrm{CO}_{2}$ and $\mathrm{H}_{2} \mathrm{O}$ was lower than the sum of the two single reaction rates, but higher than the rate of each independent reaction, for both fast char and slow char gasification. The gasification rate in a mixture of $\mathrm{H}_{2} \mathrm{O}$ and $\mathrm{CO}_{2}$ was linearly dependant on the $\mathrm{CO}_{2} \sin$ gle gasification rate. The gasification rate in mixtures of both gases could be written as a linear combination of the two single gasification rates. The regressed coefficient of $\mathrm{R}_{\left(\mathrm{CO}_{2}\right)}$ is about 0.65 and the coefficient of $\mathrm{R}_{\left(\mathrm{CO}_{2}\right)}$ is about 1 for both fast char gasification and slow char gasifica tion. Both of the results from the TGA and the fluidized bed reactor showed that the char $\mathrm{H}_{2} \mathrm{O}$ reaction was independent of char $\mathrm{CO}_{2}$ reaction, while the char $\mathrm{CO}_{2}$ reaction was inhibited by the char $\mathrm{H}_{2} \mathrm{O}$ reaction.

Umemoto et al. [17] studied the coal gasification reaction in mixed atmospheres of $\mathrm{CO}_{2}$ and $\mathrm{H}_{2} \mathrm{O}$. The coal chars were prepared in a drop tube furnace at $1673 \mathrm{~K}$. The authors performed gasification reaction in a TG apparatus. They found that the gasification reaction rate in mixed atmospheres was neither well described by a model were the $\mathrm{H}_{2} \mathrm{O}$ and $\mathrm{CO}_{2}$ react on separate active sites ( the model over predicted the exper imental data), nor by a common active site model as it under predicted the gasification rate. The authors proposed that the two reactants, $\mathrm{H}_{2} \mathrm{O}$ and $\mathrm{CO}_{2}$, partially share their respective active sites. The authors modi fied the LH expression for the chemical reaction rate term proposed by Everson et al. and introduced new parameters to account for the sharing of the active sites. The authors found that the greater contribution to the char gasification was from the steam gasification reaction. They think that this fact is due to the lower molecular size of the $\mathrm{H}_{2} \mathrm{O}$ molecule which can penetrate in all the pores.

Bai et al. [18] recently studied the coal char gasification reactivity with $\mathrm{CO}_{2}$ and $\mathrm{H}_{2} \mathrm{O}$ and their mixtures. The coal samples were pyrolyzed under an argon atmosphere at temperatures of $800^{\circ} \mathrm{C}, 900{ }^{\circ} \mathrm{C}, 1000^{\circ} \mathrm{C}$ and $1100{ }^{\circ} \mathrm{C}$ adopting slow pyrolysis operating conditions, then gasified isothermally in $\mathrm{CO}_{2}$ and $\mathrm{H}_{2} \mathrm{O}$ environments ranging from pure $\mathrm{CO}_{2}$ to pure $\mathrm{H}_{2} \mathrm{O}$ in 20 vol.\% increments. The authors found that at tempera tures of $900{ }^{\circ} \mathrm{C}, 1000^{\circ} \mathrm{C}$ and $1100^{\circ} \mathrm{C}$, the coal char has a maximum reac tivity in a $100 \% \mathrm{H}_{2} \mathrm{O}$ atmosphere. Its reactivity decreases with $\mathrm{CO}_{2}$ addition. However, at a temperature of $800^{\circ} \mathrm{C}$, the coal char has a higher reactivity in a mixed atmosphere than in pure $\mathrm{H}_{2} \mathrm{O}$ or pure $\mathrm{CO}_{2}$. Even more, the reactivity in a mixed atmosphere of $\mathrm{CO}_{2}$ and $\mathrm{H}_{2} \mathrm{O}$ was higher than the individual reactivities in $\mathrm{H}_{2} \mathrm{O}$ and $\mathrm{CO}_{2}$ respectively. The same results were obtained at $750{ }^{\circ} \mathrm{C}$. The mixed atmosphere gasification showed competition beyond $800{ }^{\circ} \mathrm{C}$ and synergy at $800{ }^{\circ} \mathrm{C}$ and below [18]. These differences were found to be linked to catalytic effects due to calcium species.

The main results on coal and lignite char gasification in complex at mospheres are summarized in Table 2.

As reported in Tables 1 and 2, mixed atmosphere gasification reac tions were tested for various biomasses and coal chars with various
Table 2

Literature review lignite and coal char gasification in complex atmospheres.

\begin{tabular}{|c|c|c|c|}
\hline References & Fuel type & Pyrolysis & $\begin{array}{l}\text { Mixed atmosphere } \\
\text { mechanism }\end{array}$ \\
\hline [12] & $\begin{array}{l}\text { Lignite char } \\
(200-900 \mu \mathrm{m})\end{array}$ & Slow pyrolysis & Competition \\
\hline [6] & $\begin{array}{l}\text { Coal char } \\
(600 \mu \mathrm{m})\end{array}$ & $\begin{array}{l}\text { Slow pyrolysis } \\
10{ }^{\circ} \mathrm{C} / \mathrm{min}\end{array}$ & Competition \\
\hline [13] & $\begin{array}{l}\text { Coal char } \\
(20-70 \mu \mathrm{m})\end{array}$ & $\begin{array}{l}\text { Slow pyrolysis } \\
20^{\circ} \mathrm{C} / \mathrm{min}\end{array}$ & Additivity \\
\hline [14] & $\begin{array}{l}\text { Coal char } \\
(20 \mu \mathrm{m})\end{array}$ & $\begin{array}{l}\text { Fast pyrolysis in FBR } \\
1000{ }^{\circ} \mathrm{C} / \mathrm{s} \text { at } 840^{\circ} \mathrm{C}\end{array}$ & Additivity \\
\hline [15] & $\begin{array}{l}\text { Coal char } \\
(63-150 \mu \mathrm{m})\end{array}$ & $\begin{array}{l}\text { Fast pyrolysis in FBR } \\
\text { at } 800^{\circ} \mathrm{C}\end{array}$ & Additivity \\
\hline [16] & $\begin{array}{l}\text { Lignite char } \\
(70-106 \mu \mathrm{m})\end{array}$ & $\begin{array}{l}\text { Slow pyrolysis } 10^{\circ} \mathrm{C} / \mathrm{min} \\
\text { Fast pyrolysis in } \mathrm{FBR} \\
\text { at } 800^{\circ} \mathrm{C}\end{array}$ & Competition \\
\hline [17] & $\begin{array}{l}\text { Coal char } \\
(40 \mu \mathrm{m})\end{array}$ & $\begin{array}{l}\text { Fast pyrolysis in DTF } \\
\text { at } 1400{ }^{\circ} \mathrm{C}\end{array}$ & Competition \\
\hline [18] & $\begin{array}{l}\text { Coal char } \\
(125 \mu \mathrm{m})\end{array}$ & $\begin{array}{l}\text { Slow pyrolysis } \\
10^{\circ} \mathrm{C} / \mathrm{min}\end{array}$ & $\begin{array}{l}\text { Synergy below } 800{ }^{\circ} \mathrm{C} \\
\text { and inhibition beyond }\end{array}$ \\
\hline
\end{tabular}

particle sizes going from several tenths of millimeter to several millime ters. The char preparation conditions as well as the gasification temper ature and gas pressure were different from one study to another. The mechanisms proposed for the mixed atmosphere gasification also differ from one study to another. These observations mean that the validity of a mechanism (additivity, competition or synergy) depends on the ex perimental conditions as well as on the nature of the char.

One ambiguous issue that is still not well clarified is the issue of in trinsic conditions. In fact, the size of a char particle and the reaction tem perature are determining factors in whether the gasification rate is controlled by the rate of chemical reactions, heat and mass transfer or both. It is acknowledged that the smaller the particle the more uniform the gas concentration and temperature inside it. In the case of concen tration and temperature uniformity inside the char particle, gasification would be chemically controlled and heat and mass transfer limitations would not influence the reaction rate. Increasing the char particle size introduces heat and mass transfer limitations, until it reaches a critical size above which heat and mass transfer limitations predominate. In several studies $[19,20]$, the authors pointed out that biomass apparent reactivity decreases when increasing the particle size, which is due to an increasing diffusional resistance.

Many authors propose a maximal particle size below which the gas ification rate is constant and is consequently performed in the chemical regime, however the values are quite disparate from one study to an other. For instance, Mermoud et al. proposed $1 \mathrm{~mm}$ as a critical size below which char steam gasification is chemically controlled at $900{ }^{\circ} \mathrm{C}$ [21]. Van De Steene et al. [22] found that the particle thickness was the characteristic dimension for parallelepiped shaped pine char. They also found that for particle thickness below $2.5 \mathrm{~mm}$, the char steam gas ification is chemically controlled at $900{ }^{\circ} \mathrm{C}$. Gomez Barea et al. [19] found that the $\mathrm{CO}_{2}$ gasification reaction of char from pressed oil stone is chemically controlled for powder char particles of $0.06 \mathrm{~mm}$, in a tem perature range of 800 to $950{ }^{\circ} \mathrm{C}$ which is quite different from the values given above. Klose et al. proposed that $\mathrm{H}_{2} \mathrm{O}$ char and $\mathrm{CO}_{2}$ char gasifica tion reactions are performed in the intrinsic regime for particle sizes below $0.125 \mathrm{~mm}$ in a temperature range of 750 to $780{ }^{\circ} \mathrm{C}$ and $10 \mathrm{mg}$ of sample mass. Isothermal gasification experiments were done in a thermogravimetric apparatus [23].

This variety of statement about intrinsic conditions shows well that it is quite difficult to state the nature of the gasification regime with as surance. It depends highly on the experimental conditions as well as on the texture of char. This issue will be discussed in the frame of the pres ent work. The first aim of the present work is to provide data on char re activity to $\mathrm{H}_{2} \mathrm{O}$ and $\mathrm{CO}_{2}$ and their mixture in practical gasification operating conditions. We also aim to evaluate the extent of diffusional limitations when varying the temperature and particle size. The aim is 
Table 3

Proximate and ultimate analyses of the beech wood-chips (\% dry basis)

\begin{tabular}{llllllll}
\hline \multicolumn{2}{l}{ Proximate analysis } & & & \multicolumn{5}{l}{ Ultimate analysis } \\
\cline { 6 - 8 } VM & Ash & FC & & C & H & O & N \\
\hline 88.1 & 0.4 & 11.5 & & 46.1 & 5.5 & 47.9 & 0.1 \\
\hline
\end{tabular}

also to shed light on the influence of temperature and char particle size on the multi component gasification reaction with $\mathrm{CO}_{2}$ and $\mathrm{H}_{2} \mathrm{O}$.

\section{Material methods}

\subsection{Low heating rate char preparation}

The raw biomass samples are beech wood spheres with a $20 \mathrm{~mm}$ di ameter. Proximate and ultimate analyses of the wood samples are given in Table 3. Low heating rate chars were prepared by a slow pyrolysis of the wood spheres under nitrogen. The pyrolysis was performed in a batch reactor. The wood spheres were placed in a metallic plateau, and spaced enough to avoid chemical and thermal interactions. The pla teau was introduced into the furnace heated zone which was progres sively heated under nitrogen from room temperature to $900{ }^{\circ} \mathrm{C}$ at $5{ }^{\circ} \mathrm{C} / \mathrm{min}$. The chars were kept for $1 \mathrm{~h}$ at the final temperature, cooled under nitrogen and stored afterwards in a sealed container. The low heating rate is expected to ensure good temperature uniformity in the wood particle and to lead to a quite homogeneous wood char, from the structural and chemical viewpoints, as demonstrated by [24] and pointed out by [25] and [26]. During the pyrolysis reaction, the char par ticles shrink and get an ovoid form. The mean particle diameter, calcu lated as the average of the three particle dimensions was estimated at $13 \mathrm{~mm}$.

Some of the $13 \mathrm{~mm}$ char particles were afterwards ground with a mortar and a pillar. Several particle size fractions, on a wide particle size ranging from $0.04 \mathrm{~mm}$ to $13 \mathrm{~mm}$, were retained for gasification ex periments: char particles of $0.04 \mathrm{~mm}$ (char004), $0.2 \mathrm{~mm}$ (char02), $0.35 \mathrm{~mm}$ (char035) and $1 \mathrm{~mm}$ (char1) screen size, and finally the $13 \mathrm{~mm}$ (char13) char particles. The wood and char samples are shown in Fig. 1.

To ensure the chemical and structural homogeneity inside the $13 \mathrm{~mm}$ char particle, the char structure and chemical composition were analysed at three locations: at the surface, at half the distance from the centre and at the centre. Elemental composition and Raman spectroscopy were used to check particle homogeneity. The Raman spectra of the chars were recorded with a WITec Confocal Raman Micro scope (WITec alpha300 R, Ulm, Germany) equipped with a Nd:YAG ex citation laser at $532 \mathrm{~nm}$. Table 4 shows the mean elemental composition of the char sample at the three locations (surface, half distance from the core and particle core). The standard deviations are quite low showing chemical composition homogeneity throughout the char particle.

Normalized Raman spectra with respect to the $G$ peak height are shown in Fig. 2a. The normalized Raman signals are identical at the three locations attesting to the structural homogeneity of the char particles. The Raman spectra show in the first order region (800 $2000 \mathrm{~cm}^{-1}$ ), two main broad and overlapping peaks with maximum in tensities at $1350 \mathrm{~cm}^{-1}$ and $1590 \mathrm{~cm}^{-1}$ [27]. In the literature, we fre quently refer to these two peaks as respectively the $D$ and $G$ bands.
Table 4

Ultimate analysis of the wood-char samples.

\begin{tabular}{lllll}
\hline $\mathrm{C}$ (wt.\%) & $\mathrm{H}$ (wt.\%) & $\mathrm{O}$ (wt.\%) (by difference) & $\mathrm{N}$ (wt.\%) & Ash (wt.\%) \\
\hline $90.83 \pm 0.93$ & $0.676 \pm 0.07$ & 7.03 & $0.21 \pm 0.027$ & $1.25 \pm 0.13$ \\
\hline
\end{tabular}

Deconvolution of the Raman signal into five bands corresponding to five carbon structures composing the char shows that the prepared char contains an amorphous phase (D3 band). The D3 band area de creases as the carbon gets ordered at higher temperatures. The D3 band is typical of disordered carbonaceous materials like coke, coal and biomass chars. These results are in accordance with those of [24] who evidenced the large char particle homogeneity when prepared in low heating rate conditions.

\subsection{Char gasification experiments in $\mathrm{H}_{2} \mathrm{O}, \mathrm{CO}_{2}$ and their mixture}

\subsubsection{The Macro TG experimental device and procedure}

The M TG device is described in detail in our previous work on char gasification in mixed atmospheres of $\mathrm{CO}_{2}$ and $\mathrm{H}_{2} \mathrm{O}$ [11]. In general terms, the experimental apparatus consists of a $2 \mathrm{~m}$ long, $75 \mathrm{~mm}$ i.d. alumina reactor that is electrically heated, and a weighing system com prising an electronic scale having an accuracy of $\pm 0.1 \mathrm{mg}$, a metallic stand placed over a scale on which a $1 \mathrm{~m}$ long, $2.4 \mathrm{~mm}$ external diameter hollow ceramic tubes are fixed. The ceramic tube holds the platinum basket in which the biomass particles are placed. The gas flow rates are controlled by means of mass flow meters/controllers. The gas flow inside the reactor is laminar and flowing at an average velocity of $0.20 \mathrm{~m} / \mathrm{s}$.

2.2.1.1. Gasification of char004 and char02. Char004 and char02 are in the form of powders. A char mass of 100 to $130 \mathrm{mg}$ is spread out on the whole surface of the $50 \mathrm{~mm}$ diameter platinum basket in the form of a very thin layer. The char mass may seem important compared to what is introduced in classical TG devices but the surface of the crucible is large enough $\left(0.002 \mathrm{~m}^{2}\right)$ to allow spreading this mass in the form of a thin layer. The char is directly exposed to the surrounding atmosphere as the platinum basket is simply in the form of a circular plane without any side wall.

2.2.1.2. Gasification of char035, char1 and char13. Char035 and those of greater sizes can be distinguished and placed individually. The char par ticles are spread over the platinum basket and spaced enough to avoid thermal and chemical interaction. For the char samples char035 and char1, about 20 to 40 particles are spread on the platinum basket. For the char13 samples, 2 particles are placed on the platinum support for a total mass of nearly $1.2 \mathrm{~g}$.

2.2.1.3. The gasification procedure. The platinum basket bearing the char particles and the ceramic tube holding it are first at room temperature. They are introduced in the hot reactor zone (which is at the gasification temperature) within less than $20 \mathrm{~s}$, under a flow of nitrogen. The system has to get stabilized thermally as well as mechanically (due to the force of the flowing nitrogen over the basket) so that the mass displayed by the electronic scale becomes constant. This can be achieved within 5 min as depicted in Fig. 3.

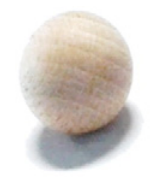

Wood20

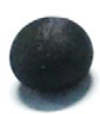

char13

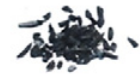

char1

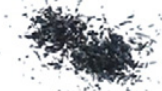

char035
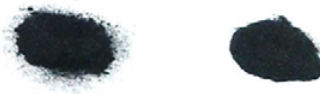

char02 char004

Fig. 1. Initial beech wood (left) sphere and derived char samples (decreasing size from left to right). 

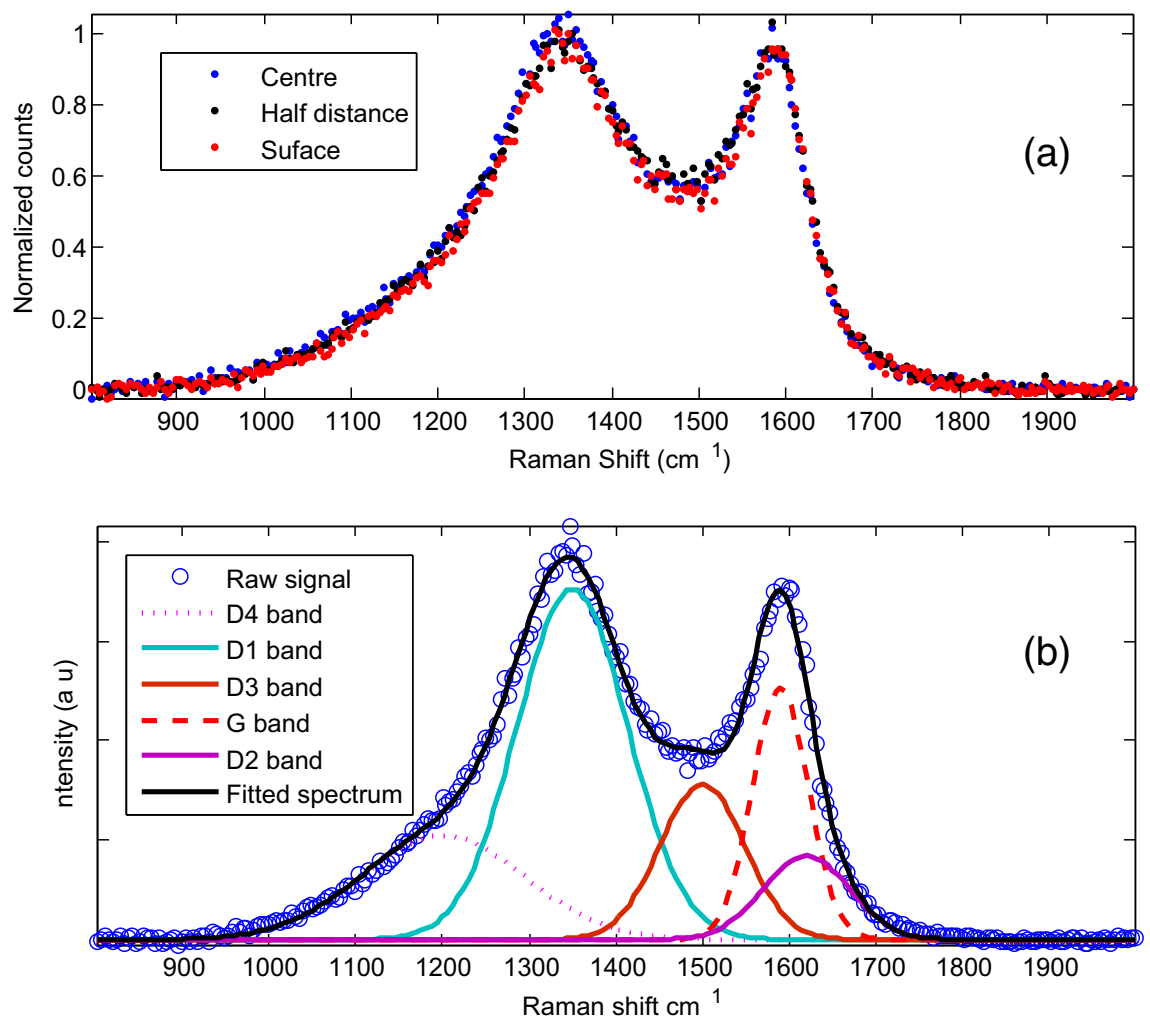

Fig. 2. Normalized Raman spectra (a) of the parent char at three locations of the particle (surface, half distance from the core and particle core) and spectrum deconvolution (b).

Afterwards, the gasification medium is introduced. The char gasifica tion experiments were performed with $\mathrm{CO}_{2}$ and $\mathrm{H}_{2} \mathrm{O}$ and their mixtures. The MTG system allows recording char mass at frequencies from $0.1 \mathrm{~s}$ to $10 \mathrm{~s}$. In the present work, the char mass was recorded per second. The data are afterwards smoothed so that we can reduce the noise in the de rivative curves of gasification rate and reactivity.

\subsubsection{Operating conditions}

The operating conditions in terms of temperature and atmosphere composition for the different char gasification reactions including single atmosphere gasification reactions, mixed atmosphere gasification and gas alternation experiments are listed in Table 5.

2.2.3. Theoretical modelling of the single atmosphere gasification reactions The char apparent reactivity towards a gas can be expressed as in the following:

$$
R(\mathrm{X})^{a p p}=\frac{1}{1-\mathrm{X}_{(\mathrm{t})}} \times \frac{d \mathrm{X}_{(\mathrm{t})}}{d \mathrm{t}}
$$

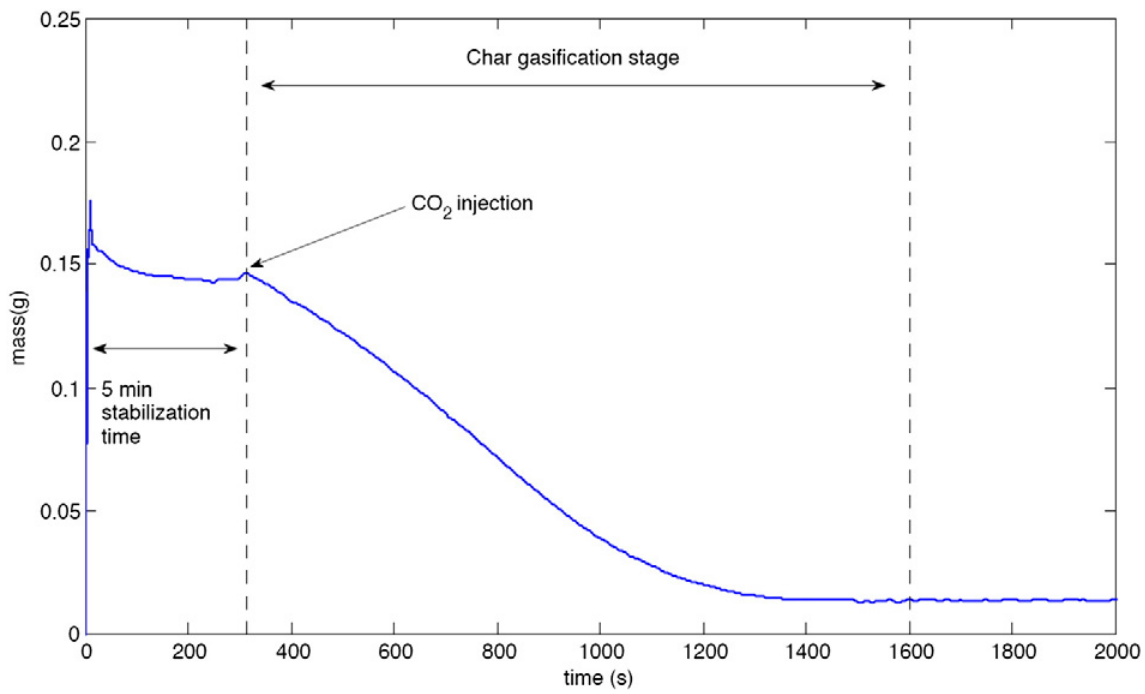

Fig. 3. Illustration of the gasification procedure (the case of $\mathrm{CO}_{2}$ gasification). 
Table 5

Char gasification experiments

\begin{tabular}{llll}
\hline Samples & $\mathrm{CO}_{2}$ gasification & $\mathrm{H}_{2} \mathrm{O}$ gasification & Mixed atmospheres \\
\hline Char004 & $900{ }^{\circ} \mathrm{C}$ & $900{ }^{\circ} \mathrm{C}$ & - \\
& $0.2 \mathrm{~atm}$ & $0.2 \mathrm{~atm}$ & - \\
Char02 & $850-900-950$ & $800-850-900$ & $900{ }^{\circ} \mathrm{C}$ \\
& $1000-1100{ }^{\circ} \mathrm{C}$ & $1000-1100{ }^{\circ} \mathrm{C}$ & $0.2+0.2 \mathrm{~atm}$ \\
& $0.2 \mathrm{~atm}$ & $0.2 \mathrm{~atm}$ & - \\
Char035 & $900{ }^{\circ} \mathrm{C}$ & $900{ }^{\circ} \mathrm{C}$ & - \\
& $0.2 \mathrm{~atm}$ & $0.2 \mathrm{~atm}$ & - \\
Char1 & $900{ }^{\circ} \mathrm{C}$ & $900{ }^{\circ} \mathrm{C}$ & - \\
& $0.2 \mathrm{~atm}$ & $0.2 \mathrm{~atm}$ & - \\
Char13 & $900{ }^{\circ} \mathrm{C}$ & $900{ }^{\circ} \mathrm{C}$ & $900{ }^{\circ} \mathrm{C}$ \\
& $0.2 \mathrm{~atm}$ & $0.2 \mathrm{~atm}$ & $0.2+0.2 \mathrm{~atm}$ \\
\hline
\end{tabular}

where $\mathrm{X}$ is the conversion level given by:

$\mathrm{X}_{(t)}=\frac{m_{0}-m_{(\mathrm{t})}}{m_{0}-m_{\text {ash }}}$

where $m_{0}, m_{t}$ and $m_{a s h}$ are respectively the initial mass of char, the mas at time $t$ and the mass of the residual ash. If the gasification reaction is performed in the chemical regime (relatively low temperature and small particle size), the calculated reactivity would be the intrinsic one. As stated above, char reactivity depends on the operating condi tions (temperature and reactant gas pressure), and char properties (tex ture, mineral content, structure). It is thus commonly expressed as the product of reference reactivity $R(X r e f)_{\left(T, P_{i}\right)}$ (depending on the tempera ture and reactant gas pressure) and a structural term $f(X)$ accounting for the char property evolution along the conversion. Owing to the difficul ties in the monitoring of the intrinsic char properties along the conver sion, the structural term is usually an empirical correlation where the conversion level appears as the sole variable. Changes in the char intrin sic properties are implicitly described by this empirical term. The refer ence reactivity corresponds to a specific conversion level. Reference reactivity at $10 \%$ or $50 \%$ of conversion has been used in the literature $[19,28,29]$. The reactivity at the $50 \%$ conversion level $(R(50))$ is most frequently used as a reference value. The reactivity at any gasification stage can be thus expressed as:

$R(\mathrm{X})_{\left(T, P_{i}\right)}^{\text {int }}=R(50)_{\left(T, P_{i}\right)}^{\text {int }} f(\mathrm{X})$

where $R(50)_{\left(T, P_{\mathrm{i}}\right)}^{\mathrm{int}}$ is the intrinsic reactivity at $\mathrm{X}=50 \%$ and $f(\mathrm{X})$ is the structural function expression describing the evolution of the char prop erties during the gasification.

nth order kinetics are often used to express the temperature and $\mathrm{CO}_{2}$ pressure dependence of $R(50)_{\left(T, P_{i}\right)}^{\text {int }}$. By assuming Arrhenius type ki netics for the kinetic constant, the intrinsic reactivity can have the fol lowing expression:

$R(50)_{\left(T, P_{i}\right)}^{i n t}=M_{C} S_{r} k_{(T)} P_{g}^{n}$

where $M_{C}$ is the carbon molecular weight, $S_{r}$ is the reactive surface $\left(\mathrm{m}^{2} \cdot \mathrm{kg}^{-1}\right), k_{(T)}$ the kinetic rate constant of char gasification $\left(\mathrm{mol} \cdot \mathrm{s}^{-1} \cdot \mathrm{m}^{2} \cdot \mathrm{atm}^{-\mathrm{n}}\right)$ and $P_{\mathrm{g}}$ is the reacting gas partial pressure at the particle surface $(\mathrm{atm})$.

$k_{(T)}$ is expressed following an Arrhenius type law:

$k_{(T)}=A \exp \frac{-E}{R T}$

where $A$ is the pre exponential factor $\left(\mathrm{mol} \cdot \mathrm{s}^{-1} \cdot \mathrm{m}^{2} \cdot \mathrm{atm}^{-\mathrm{n}}\right), E$ is the char gasification activation energy $(\mathrm{J} / \mathrm{mol}), R$ is the universal gas con stant $(\mathrm{J} /(\mathrm{mol} \cdot \mathrm{K}))$ and $T$ is the temperature $(\mathrm{K})$.

For macroscopic char particles, there exist diffusional limitations [19]. One can no longer speak about a volumetric reaction rate (intrin sic) as the gas concentration inside the particle is not uniform. In this kind of situation there is a competition between gas diffusion and reac tion inside the char particle. To model such a situation, one must solve the gas mass and energy conservation equations along the reaction to obtain the gas concentration profiles at any time and any location in the particle [20]. Although it is rigorous, numerical modelling requires too high computing capacities. There exist alternative methods for
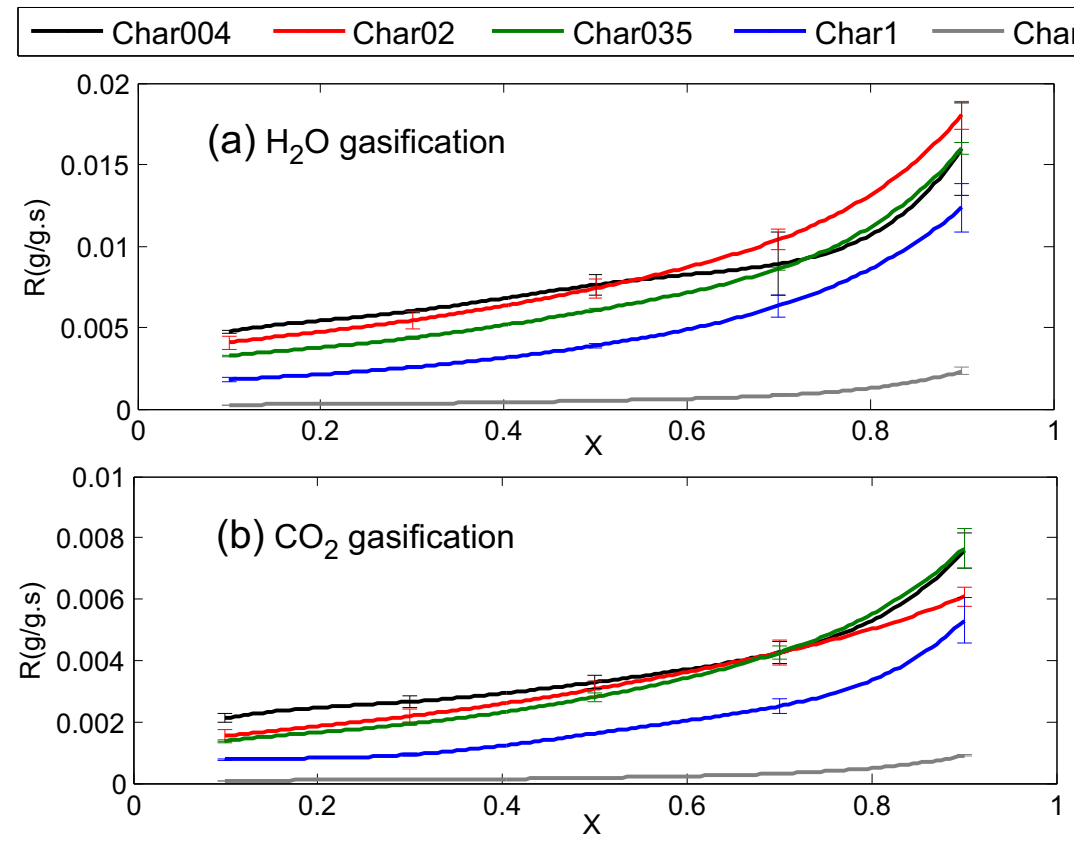

Fig. 4. Influence of particle size on the char gasification reactivity at $900{ }^{\circ} \mathrm{C}$ with $20 \% \mathrm{H}_{2} \mathrm{O}$ (a) and with $20 \% \mathrm{CO}_{2}$ (b). 
formulating the apparent gasification reaction rate. The simplest meth od is using the pseudo activation energy which changes with tempera ture. However, this method cannot express the effect of the particle size and is poorly describing the physical phenomena. The evolution of the gasification rate with particle size can be described through a semi empirical expression, where the apparent reaction rate is expressed as a function of the intrinsic reaction rate and the particle size [30]. The third method consists of the effectiveness factor approach to take into account the diffusion reaction competition [31 34]. We will use this method in the present work to account for diffusional limitations when varying the char particle size or temperature.

The effectiveness factor approach originates from the catalyst theory. In the presence of diffusion reaction competition, Thiele [35] defined an effectiveness factor $\eta$ which is the ratio of the apparent reac tion rate to the intrinsic one. It allows taking into account the consump tion of the reactant gas while it diffuses inside the porous particle. It is equal to unity in the absence of diffusional limitations and tends to wards zero in the presence of high diffusional limitations. Using the ef fectiveness factor, the apparent reactivity reads:

$R(50)_{\left(T, P_{i}\right)}^{a p p}=\eta R(50)_{\left(T, P_{i}\right)}^{i n t}$

with $\eta$ being the Thiele effectiveness factor.

The reaction order of biomass char gasification differs from one study to another. In Di Blasi's review, $\mathrm{CO}_{2}$ char gasification reaction order varies between 0.36 and 1.2 and that of $\mathrm{H}_{2} \mathrm{O}$ char gasification is comprised between 0.4 and 1 [2]. When using the effectiveness factor approach to model the effect of LHR char gasification, we will consider the gasification reactions as first order reactions. The definition of the ef fectiveness factor is rigorous only for a first order reaction. The effective ness factor expression is obtained by volume integration of the reactant gas balance equation and has the following expression for spherical particles:

$\eta=\frac{3}{\phi}\left(\frac{1}{\tan h \phi}-\frac{1}{\phi}\right)$.

The Thiele modulus $\phi$ has the following expression:

$\phi=\frac{d_{\text {part }}}{2} \sqrt{\frac{\beta S_{v} k_{(T)} P_{g}}{M_{g} D i_{e f f} C_{g}}}$

where $d_{\text {part }}$ is the particle diameter ( $\left.\mathrm{m}\right), \beta$ is a stoichiometric coefficient equal to the ratio between the gas molar mass and that of carbon, $S_{v}$ is a volumetric surface $\left(\mathrm{m}^{2} / \mathrm{m}^{3}\right), M_{g}$ is the molecular weight of the reactant gas $\left(\mathrm{kg} \cdot \mathrm{mol}^{-1}\right), C_{g}$ is the bulk concentration of the reactant gas $\left(\mathrm{mol} \cdot \mathrm{m}^{-3}\right)$ and $D i_{e f f}$ is the effective diffusion coefficient $\left(\mathrm{m}^{2} / \mathrm{s}\right)$.

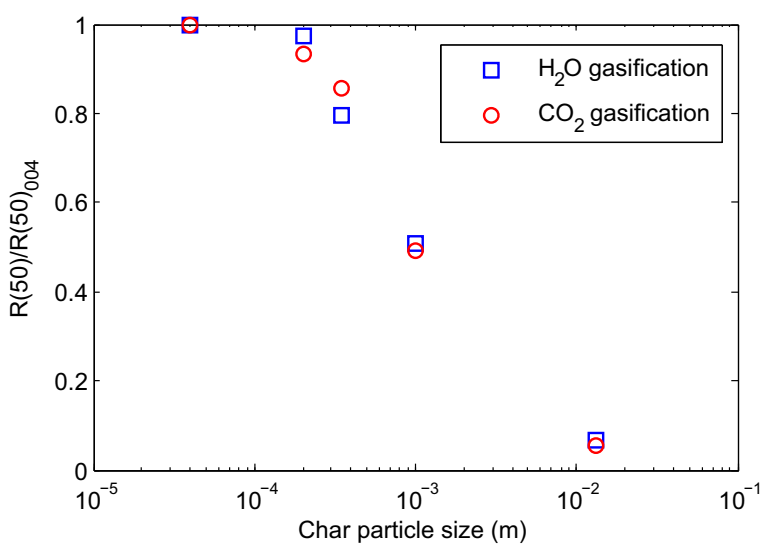

Fig. 5. Normalized $\mathrm{R}(50)$ with respect to that of char004 for $\mathrm{H}_{2} \mathrm{O}$ and $\mathrm{CO}_{2}$ gasification.
For a gas " $\mathrm{i}$ " $\left(\mathrm{CO}_{2}\right.$ or $\left.\mathrm{H}_{2} \mathrm{O}\right), D i_{\text {eff }}$ is expressed through the molecular diffusion coefficient $D i_{m o l}$ and the Knudsen diffusion coefficient Di $i_{\text {Knudsen: }}$ :

$$
\begin{aligned}
& D i_{\text {eff }}=\frac{1}{\frac{1}{D_{\text {Knudsen }}}+\frac{1}{D i_{\text {mol }}}} \\
& D i_{\text {mol }}=a_{i} 10^{-5}\left(\frac{T}{298}\right)^{1.75} \\
& D i_{\text {Knudsen }}=\frac{\varepsilon}{\tau} 0.97 \frac{d_{\text {pore }}}{2}\left(\frac{T}{M_{i}}\right)^{0.5}
\end{aligned}
$$

where $a_{i}$ is a constant taken to be 1.67 for $\mathrm{CO}_{2}$ and 2.1 for $\mathrm{H}_{2} \mathrm{O}$ [33], $d_{\text {pore }}$ is the pore diameter $(\mathrm{m}), \varepsilon$ is the char porosity and $\tau$ is the char tortuosity.

Several authors used the effectiveness factor approach to model the char combustion and gasification reaction for different temperatures and particle sizes [19,31,33 34,3638]. The effectiveness approach ren ders the calculation of the char reactivity straightforward. Despite it not gathering all the physics of the gasification reaction, it is a simple meth od allowing the prediction of the char apparent reactivity without enor mous computational effort.

2.2.3.1. Modelling procedure. At $50 \%$ of conversion we adopted a char po rosity of 0.95 , a tortuosity of 3 and an apparent density of $250\left(\mathrm{~kg} / \mathrm{m}^{3}\right)$ (the initial density after pyrolysis is around $500\left(\mathrm{~kg} / \mathrm{m}^{3}\right)$ ). We measured the Total Surface Area of char02 at $\mathrm{X}=0.5$ by $\mathrm{N}_{2}$ adsorption at $77 \mathrm{~K}$. The values were $1230\left(\mathrm{~m}^{2} / \mathrm{g}\right)$ for $\mathrm{H}_{2} \mathrm{O}$ gasification and $840\left(\mathrm{~m}^{2} / \mathrm{g}\right)$ for the $\mathrm{CO}_{2}$ gasification. We used these values for the parameter $S_{r}$ as well as in the calculation of $S_{v}$ which is the product of $S_{r}$ by the apparent density.
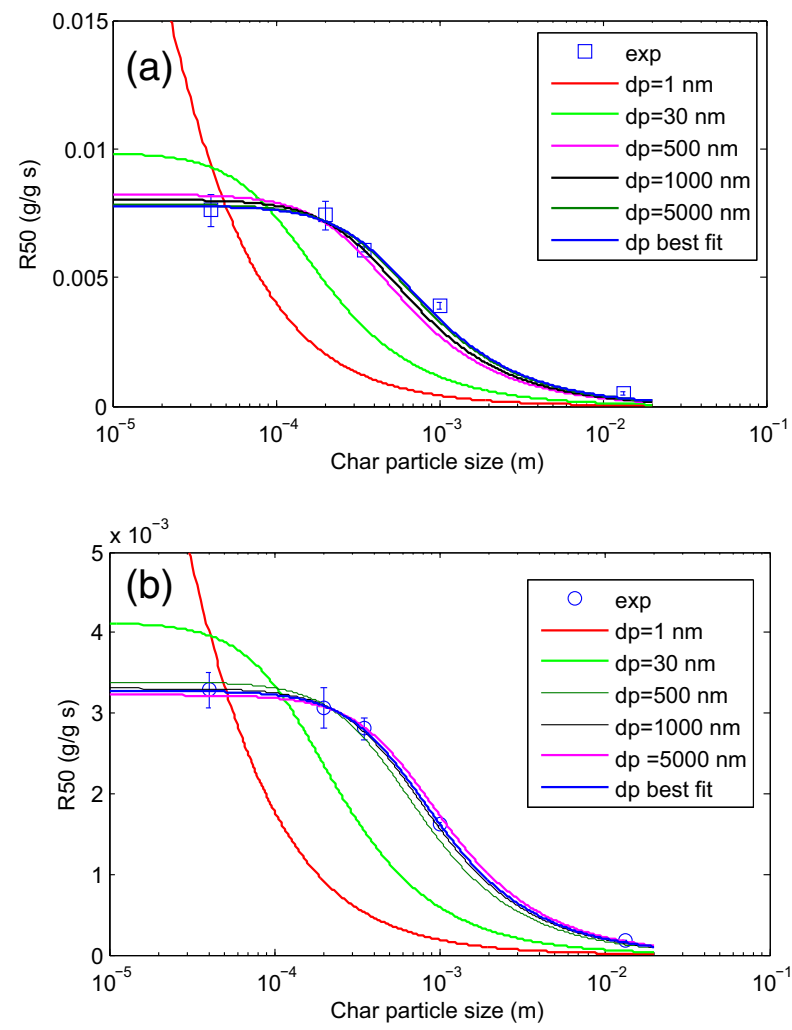

Fig. 6. Experimental $\mathrm{R}(50)$ and Thiele model for $\mathrm{H}_{2} \mathrm{O}$ (a) and $\mathrm{CO}_{2}$ (b) char gasification at $900{ }^{\circ} \mathrm{C}$. 


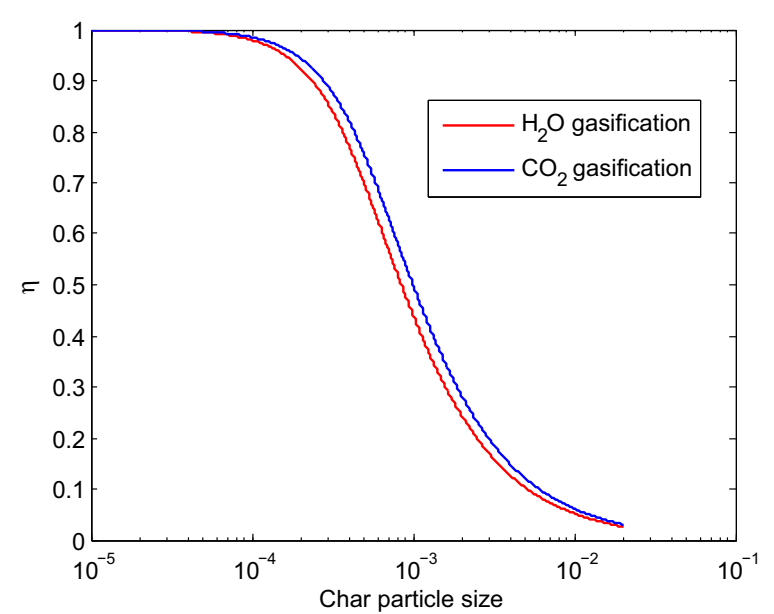

Fig. 7. Evolution of the effectiveness factor with the char particle size for $\mathrm{H}_{2} \mathrm{O}$ and $\mathrm{CO}_{2}$ gasification at $900{ }^{\circ} \mathrm{C}$

In the Thiele modulus expression, there are three unknown parame ters that will be determined by best fitting the model to the experimental data. These parameters are $d_{\text {pore }}$ in the effective diffusivity expression, A and $\mathrm{E}$ in the rate constant expression. $d_{\text {pore }}$ and $k_{900}$ are determined first by fitting the experimental $\mathrm{R}(50)$ data obtained at $900{ }^{\circ} \mathrm{C}$ for char004, char02, char035, char 1 and char 13 with the model. $A$ and $\mathrm{E}$ are afterwards determined by best fitting the experimental $\mathrm{R}(50)$ data obtained for the char02 at different temperatures: $800{ }^{\circ} \mathrm{C}, 850{ }^{\circ} \mathrm{C}$, and $900{ }^{\circ} \mathrm{C}$ for $\mathrm{H}_{2} \mathrm{O}$ gas ification, and $850^{\circ} \mathrm{C}, 900{ }^{\circ} \mathrm{C}, 950^{\circ} \mathrm{C}$ and $1000^{\circ} \mathrm{C}$ for $\mathrm{CO}_{2}$ gasification.

$d_{\text {pore }}, \mathrm{A}$ and $\mathrm{E}$ are determined by the minimisation of the following objective function:

$O F=\sum_{j}^{n}\left(R(50)_{j}^{\text {model }}-R(50)_{j}{ }^{\exp }\right)^{2}$

\subsubsection{Mixed atmosphere gasification reaction modelling}

In the present work, we propose to model the mixed atmosphere re activity as a linear combination of the single reactivities with $\mathrm{CO}_{2}$ and $\mathrm{H}_{2} \mathrm{O}$ following:

$R($ mix $)=\alpha R_{\left(\mathrm{H}_{2} \mathrm{O}\right)}+\beta R_{\left(\mathrm{CO}_{2}\right)}$.
In the case of passive cooperation, the char reactivity in the mixed atmosphere is equal to the sum of the individual reactivities, and $\alpha$ and $\beta$ would be both equal to 1 . In the case where the two gases compete for the same active sites, the global reactivity is lower than the sum of the individual ones. $\alpha$ and $\beta$ would vary between 0 and 1 without both reaching unity (in the case of passive coopera tion). If $\alpha$ or $\beta$ equals zero, only one gas is operating while the other is a spectator. Intermediate values depict the contribution of the gases to the global reaction. If there is a synergy, the global reactivity is higher than the sum of the individual ones. One or both coefficients will be higher than 1 .

In the present work, we study the variation of these coefficients with the temperatures $\left(800{ }^{\circ} \mathrm{C}, 900{ }^{\circ} \mathrm{C}, 1000^{\circ} \mathrm{C}\right.$ and $\left.1100^{\circ} \mathrm{C}\right)$ for the $0.2 \mathrm{~mm}$ size particles, as well as the variation with the char particle sizes consid ering the char02, char5 and char13 sample gasification at $900{ }^{\circ} \mathrm{C}$.

$\alpha$ and $\beta$ are determined by the minimisation of the following objec tive function:

$\mathrm{OF}=\sum_{j 1}^{n}\left(R(\text { mix })_{j}^{\text {model }}-R(\text { mix })_{j}{ }^{\text {exp }}\right)^{2}$.

This approach assumes that the contributions of the $\mathrm{H}_{2} \mathrm{O}$ and $\mathrm{CO}_{2}$ gasification reactions are constant along the reaction.

\section{Results and discussion}

3.1. Effects of particle size on char gasification reactivity in single atmo spheres of $\mathrm{H}_{2} \mathrm{O}$ and $\mathrm{CO}_{2}$

Fig. 4 shows the influence of particle size on the char gasification re activity towards $\mathrm{H}_{2} \mathrm{O}$ (a) and $\mathrm{CO}_{2}$ (b) gasification. It can be clearly seen that the char reactivity decreases when increasing the particle size due to increasing diffusional limitations. Char02 reactivities are quite close to that of char004 for both $\mathrm{H}_{2} \mathrm{O}$ and $\mathrm{CO}_{2}$ gasification. This means that at $900{ }^{\circ} \mathrm{C}$ and for these particle sizes the gasification conditions ap proach the intrinsic ones. Fig. 4 also shows that for high conversion levels and low particle sizes ( $0.04 \mathrm{~mm}$ and $0.2 \mathrm{~mm}$ ), the char reactivity shows unexpected trends. For instance, considering steam gasification, the reactivity of char004 becomes very similar to that of char02 at $\mathrm{X}=0.5$ but then dropped below it. In the same way, considering $\mathrm{CO}_{2}$ gasification, char004, char02 and char035 exhibited the same reactivity

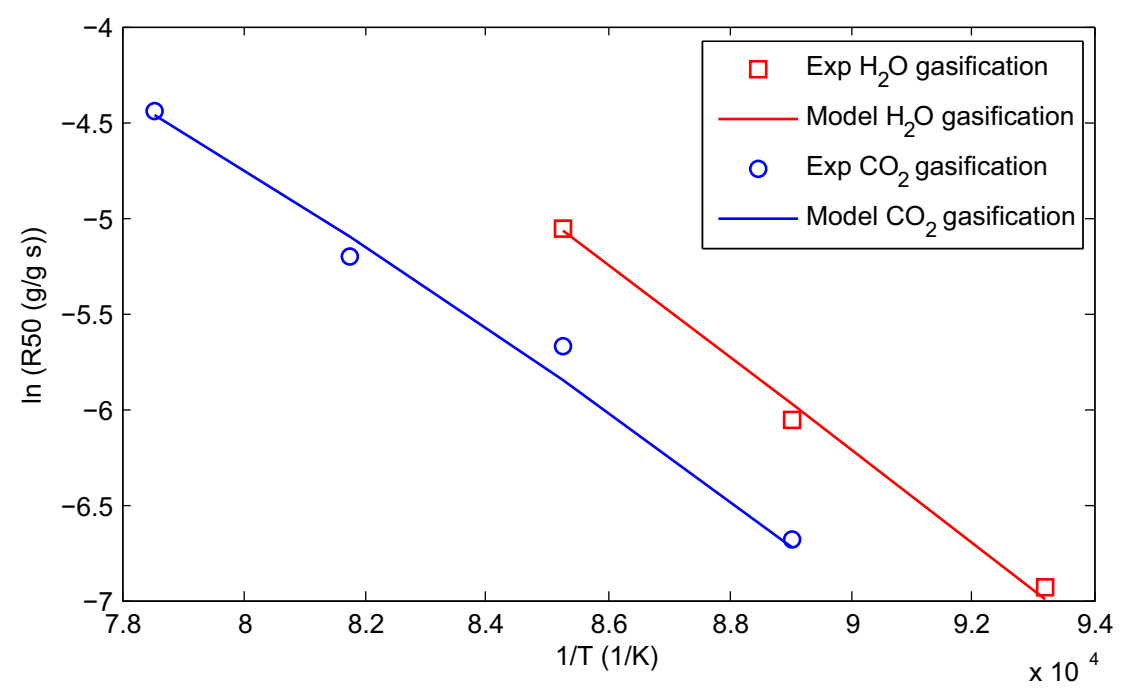

Fig. 8. Arrhenius plots for $\mathrm{H}_{2} \mathrm{O}$ and $\mathrm{CO}_{2}$ gasification: experimental data and models. 
Table 6

Kinetic parameters.

\begin{tabular}{lll}
\hline & $\mathrm{E}\left(\mathrm{kJ} \cdot \mathrm{mol}^{1}\right)$ & $\mathrm{A}\left(\mathrm{kg} \cdot \mathrm{s}^{1} \cdot \mathrm{m}^{2} \cdot \mathrm{atm}{ }^{1}\right)$ \\
\hline $\mathrm{H}_{2} \mathrm{O}$ gasification & 207.95 & $4.1610^{3}$ \\
$\mathrm{CO}_{2}$ gasification & 202.19 & $1.5610^{3}$ \\
\hline
\end{tabular}

at $\mathrm{X}=0.7$. The reactivity of char004 and char02 was equal for higher conversion levels while that of char02 was lower.

Observations derived from the present study as well as from previ ous ones on char gasification showed that at high conversion levels there are many phenomena that we do not really master or understand. We observed, as well as other authors, many unexpected reactivity be haviours beyond $70 \%$ of conversion that change with the type of reacting gas, particle size, pyrolysis atmosphere or temperature. We think that there are several factors (retention/volatilisation of minerals, fragmentation, shrinking) whose effects are different according to parti cle size, temperature and reacting gas, and which are accentuated at higher conversion levels $[2,5,20,22,39,40]$. As the experimental repeat ability is good, and as it can be deduced from the error bars, we think that these results are related to the gasification mechanism rather than to repeatability issues. Our research is ongoing to understand what phenomena are involved at the final stages of gasification.

The normalized $\mathrm{R}(50)$ for the different particle sizes with respect to the $\mathrm{R}(50)$ of char004 is illustrated in Fig. 5. A semi log scale is adopted for a better representation. For the two gasification reactions, increasing the char particle beyond $0.04 \mathrm{~mm}$ induced nearly the same relative re activity decrease. This result indicates the equivalence of the reaction diffusion competition for the two gasification reactions. This will be discussed in more detail in the next paragraphs.

Fig. 6 shows the experimental $R(50)$ as well as the Thiele model pre dictions for $\mathrm{H}_{2} \mathrm{O}$ (a) and $\mathrm{CO}_{2}$ (b) char gasification at $900{ }^{\circ} \mathrm{C}$. As explained above this first step allows determining the best average pore diameter to fit with experimental results. For both $\mathrm{H}_{2} \mathrm{O}$ and $\mathrm{CO}_{2}$ gasification, the pore size for which we obtain the best fit is in the macropore size range. For $\mathrm{H}_{2} \mathrm{O}$ gasification, we found that the best fit is given for a very high pore diameter (a value that has no physical meaning), but when plotting the sum of squared residuals between the experimental data and model prediction as a function of the pore diameter, we ob served that this error is constant for pore sizes higher than $1 \mu \mathrm{m}$. As shown in Fig. 6 fixing the pore diameter to $1 \mu \mathrm{m}$ or $5 \mu \mathrm{m}$ gives quite sat isfactory results. In the case of $\mathrm{H}_{2} \mathrm{O}$ gasification the pore size would be higher than $1 \mu \mathrm{m}$. For $\mathrm{CO}_{2}$ gasification, the best fit was obtained for a pore size of $1.5 \mu \mathrm{m}$. Similarly, when plotting the sum of squared resid uals between the experimental data and model prediction as a function of the pore diameter, we obtained a minimum around this value but the experimental data still well represented pore sizes in the range of 0.5 to $5 \mu \mathrm{m}$. This range of pores would be most influencing during $\mathrm{CO}_{2}$ gasifi cation. These results mean that the gasification reactions are mainly oc curring in macropores. Some authors think that mesopores and macropores are better indicators of the char reactivity. The contribution of micropores to the active surface area is thought to be negligible com pared to that of macropores and large mesopores [26]. To assess if the model captures the experimental data for other pore sizes, we fixed the pore size at some specific values: $1 \mathrm{~nm}$ (micropores), $30 \mathrm{~nm}$ (mesopores) and $1000 \mathrm{~nm}$ (macropores) and searched for $k_{900}$ that al lows the best fit to the experimental results. As shown in Fig. 6, neither pore size representative of micropores nor one representative of mesopores allows to capture the experimental $\mathrm{R}(50)$. It can also be seen that for the char004, both gasification reactions are performed in the chemical regime. The experimental R50 points for the char004 are located in the plateau given by the model so that further reducing the char particle size will not modify the char reactivity.

Diffusional limitations increase with increasing particle size. To illus trate the extent of the diffusional limitations, we present in Fig. 7, the evolution of the effectiveness factor with char particle size for $\mathrm{H}_{2} \mathrm{O}$ and $\mathrm{CO}_{2}$ gasification at $900{ }^{\circ} \mathrm{C}$. The similarity in the evolution if $\eta$ with the particle size means that the reaction diffusion competition is similar for both gasification reactions. However, $\mathrm{H}_{2} \mathrm{O}$ is found to react and diffuse faster than the $\mathrm{CO}_{2}$ molecule which has lower chemical reactivity and

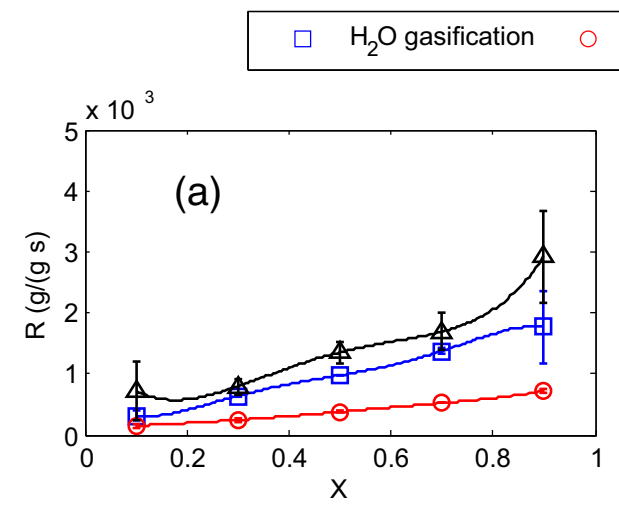

$\mathrm{CO}_{2}$ gasification $\triangle$ Mix gasification
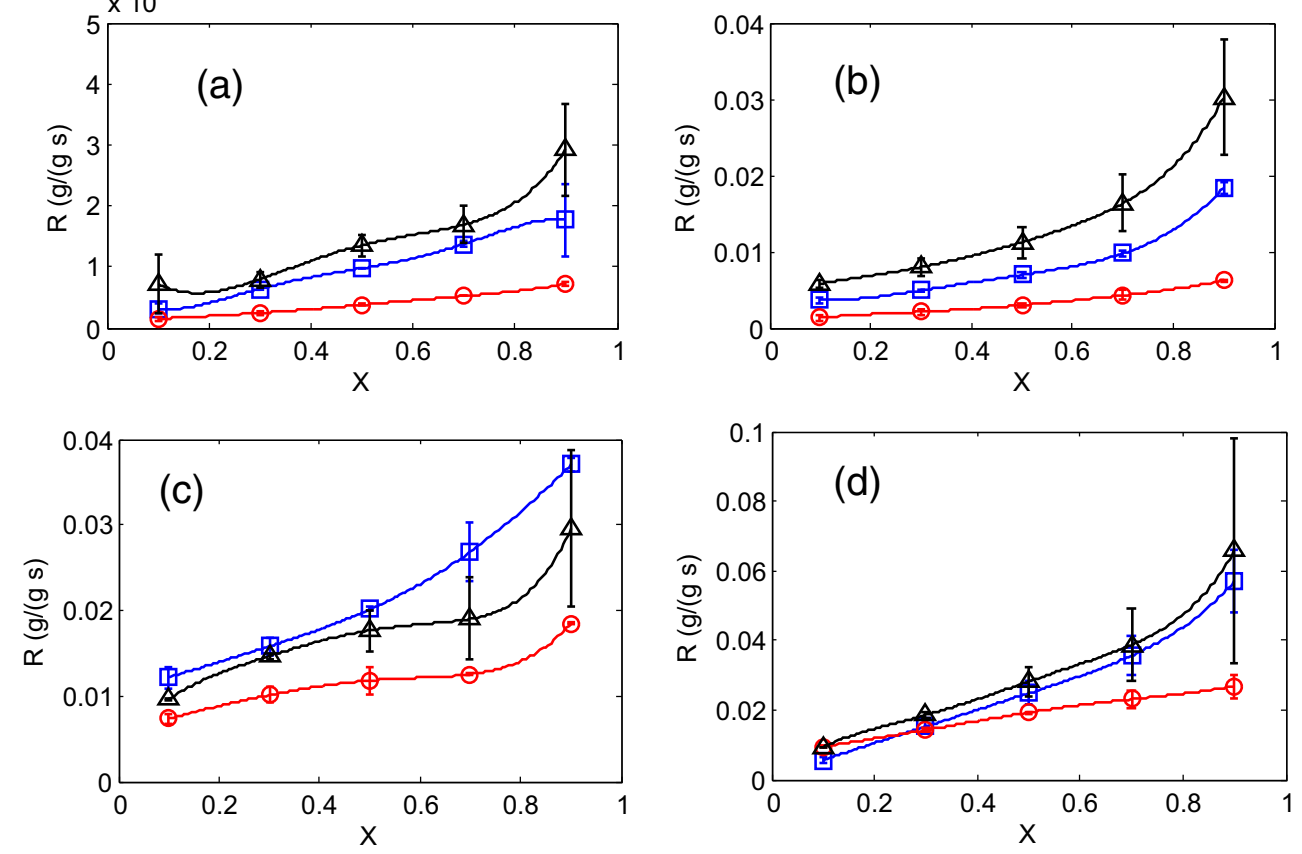

Fig. 9. Char02 gasification reactivity in $20 \% \mathrm{H}_{2} \mathrm{O}, 20 \% \mathrm{CO}_{2}$ and $20 \% \mathrm{H}_{2} \mathrm{O}+20 \% \mathrm{CO}_{2}$ at $800{ }^{\circ} \mathrm{C}$ (a), $900{ }^{\circ} \mathrm{C}\left(\right.$ b), $1000{ }^{\circ} \mathrm{C}(\mathrm{c})$ and $1100{ }^{\circ} \mathrm{C}(\mathrm{d})$. 
diffusivity due to its bigger molecular size. The ratio of $\mathrm{H}_{2} \mathrm{O}$ and $\mathrm{CO}_{2}$ reac tivities is around 2 while the effective diffusive coefficients are $5.10^{-5} \mathrm{~m}^{2} / \mathrm{s}$ for $\mathrm{H}_{2} \mathrm{O}$ and $3.10^{-5} \mathrm{~m}^{2} / \mathrm{s}$ for $\mathrm{CO}_{2}$. It can be seen in this figure that for both reactions increasing the particle size from $0.04 \mathrm{~mm}$ to $13 \mathrm{~mm}$ induced the reactivity to decrease by more than twenty folds.

The kinetic parameters, namely A and $\mathrm{E}$ were determined by fitting the $\mathrm{R}(50)$ data for char02 with the Thiele model at various temperatures for the $\mathrm{H}_{2} \mathrm{O}$ and $\mathrm{CO}_{2}$ gasification reactions. Arrhenius plots are shown in Fig. 8 for both reactions. The model fits quite well to the experiments. The values of $A$ and $E$ are given in Table 6 . They match well with the values given in Di Blasi's review on lignocellulosic biomass char gasifica tion with $\mathrm{CO}_{2}$ and $\mathrm{H}_{2} \mathrm{O}$ [2]. The activation energies for both reactions are around $200 \mathrm{~kJ} / \mathrm{mol}$ which is quite close to the findings of [23] who found equivalent values for beech wood char gasification with $\mathrm{H}_{2} \mathrm{O}$ and $\mathrm{CO}_{2}$.

We found that for the $0.2 \mathrm{~mm}$ particle size, both gasification reac tions would be performed in the chemical regime at $800{ }^{\circ} \mathrm{C}$ with $\eta$ being very close to one. Diffusional limitations become non negligible at $900{ }^{\circ} \mathrm{C}$ with an effectiveness factor of around 0.92 . At $1000^{\circ} \mathrm{C}$, the ef fectiveness factor for both reactions is around 0.7 for the $0.2 \mathrm{~mm}$ sized char particles.

\subsection{Gasification experiments in mixed atmospheres of $\mathrm{H}_{2} \mathrm{O}$ and $\mathrm{CO}_{2}$}

\subsubsection{Effect of temperature on the mixed atmosphere gasification}

The effect of temperature on mixed atmosphere gasification was studied for the char02 sample. Char02 gasification reactivities in single and mixed atmospheres of $\mathrm{H}_{2} \mathrm{O}$ and $\mathrm{CO}_{2}$ at $800{ }^{\circ} \mathrm{C}, 900{ }^{\circ} \mathrm{C}, 1000{ }^{\circ} \mathrm{C}$ and $1100^{\circ} \mathrm{C}$ are shown in Fig. 9. It can be seen in the figure that the char re activity towards $\mathrm{H}_{2} \mathrm{O}$ is higher than that towards $\mathrm{CO}_{2}$ at all tempera tures, except in the very beginning of the reaction at $1100{ }^{\circ} \mathrm{C}$ where the reactivity to $\mathrm{CO}_{2}$ was a little bit higher. We think that this observa tion is related to morphological modifications or loss of catalysts occur ring at high temperatures. With the reaction unfolding, $\mathrm{H}_{2} \mathrm{O}$ reactivity was higher than that of $\mathrm{CO}_{2}$ reactivity.

Concerning mixed atmosphere gasification, we can observe that the reactivity in the mixed atmosphere of $20 \% \mathrm{H}_{2} \mathrm{O}+20 \% \mathrm{CO}_{2}$ is higher than the reactivity towards steam at 800 and $900^{\circ} \mathrm{C}$. The sum of the individ ual reactivities approaches that observed in mixed atmosphere gasifica tion. We may think that at these temperatures the two gases react separately without any kind of inhibition. At these temperatures and for a total partial pressure of reacting molecules of $40 \mathrm{~mol} \%$, there would be enough active sites for the two gases to react on. At $1000{ }^{\circ} \mathrm{C}$ inhibition was observed. The reactivity in the mixed atmosphere is lower than that with steam alone but higher than that obtained under $\mathrm{CO}_{2}$ atmosphere. At $1100{ }^{\circ} \mathrm{C}$, the char reactivity at the very beginning is similar to that obtained at $1000^{\circ} \mathrm{C}$. At these two temperatures, the re action kinetics becomes quite fast and there would exist high diffusional limitations. The reacting gases react only on a portion of the active area and the concentration of active sites is therefore reduced. There is con sequently a manifestation of competition resulting in a reactivity in mixed atmospheres lower than that of the sum of the individual reactiv ities. In addition, the competition mechanism may be accentuated by
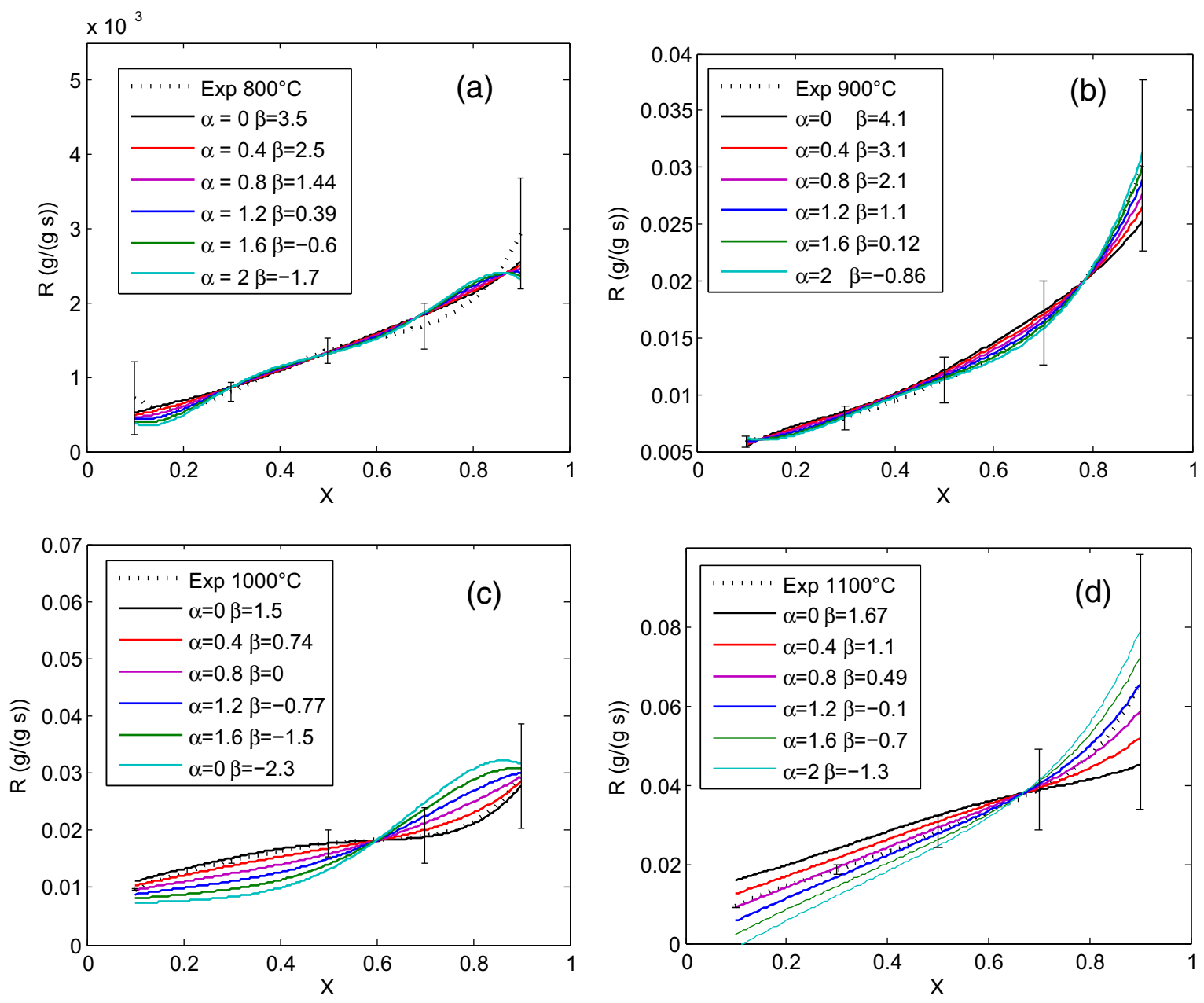

Fig. 10. Modelled mixed atmosphere reactivities for different combinations of $\alpha$ and $\beta$ and their confrontation to the experimental results at $800{ }^{\circ} \mathrm{C}\left(\mathrm{a}\right.$ ), $900{ }^{\circ} \mathrm{C}$ (b), $1000{ }^{\circ} \mathrm{C}(\mathrm{c})$ and $1100{ }^{\circ} \mathrm{C}(\mathrm{d})$. 
structural modifications at higher temperatures, thermal annealing by an ordering of the carbonaceous matrix and loss of functional groups constituting the active sites [41]. A reduced catalytic effect can be also at the origin of this observation, as catalytic species like $\mathrm{K}, \mathrm{Ca}, \mathrm{Mg}$ or $\mathrm{Na}$ may volatilize or sinter at high temperature [42]. A high temperature reaction can contribute to an increase in the volatility of catalytic species [43]. The combination of experimental parameters of temperature, active site concentration and reacting gas partial pressure determine the extent of competition or reaction on separate active sites as proposed recently by Roberts et al. [44]. Owing to these results we can conclude that the gasification mechanism varies with the type of char (active site concentration, presence of catalytic species), the temperature (influencing the reaction rate and char properties) and reacting molecule concentration (active site saturation).

The experiments as well as the modelling results on char reactivity on mixed atmospheres are shown in Fig. 10. In the modelling procedure, $\alpha$ and $\beta$ that ensure the best fit to the experiments are given for the low est value of the objective function. However, there may be several com binations of $\alpha$ and $\beta$ that may give satisfactory results. In order to check if the solutions obtained for the different temperatures are unique, we fixed manually, in a second modelling run, the value of $\alpha$ and searched that of $\beta$ that gives the best fit to the experimental data. $\alpha$ was varied be tween 0 and 2 by a step of 0.4

At $800^{\circ} \mathrm{C}$, the gasification reaction is thought to be performed in the chemical regime. The reactivity in the mixed atmosphere is best de scribed by an additive law since $\alpha=\beta=1$ according to the optimisa tion procedure. Nevertheless, regardless of the combination of $\alpha$ and $\beta$, the modelled reactivity is found in the range of the experimental standard deviation zone. For $\beta$ to remain positive, $\alpha$ must be in the range of 0 to 1.35 which is quite a wide range to state about the mech anism of mixed atmosphere gasification at $800{ }^{\circ} \mathrm{C}$. Similarly at $900{ }^{\circ} \mathrm{C}$, while $\alpha$ is comprised between 0 and 1.65, all combinations of $\alpha$ and $\beta$ give satisfactory results. The reactivity curve is in the experimental stan dard deviation zone.
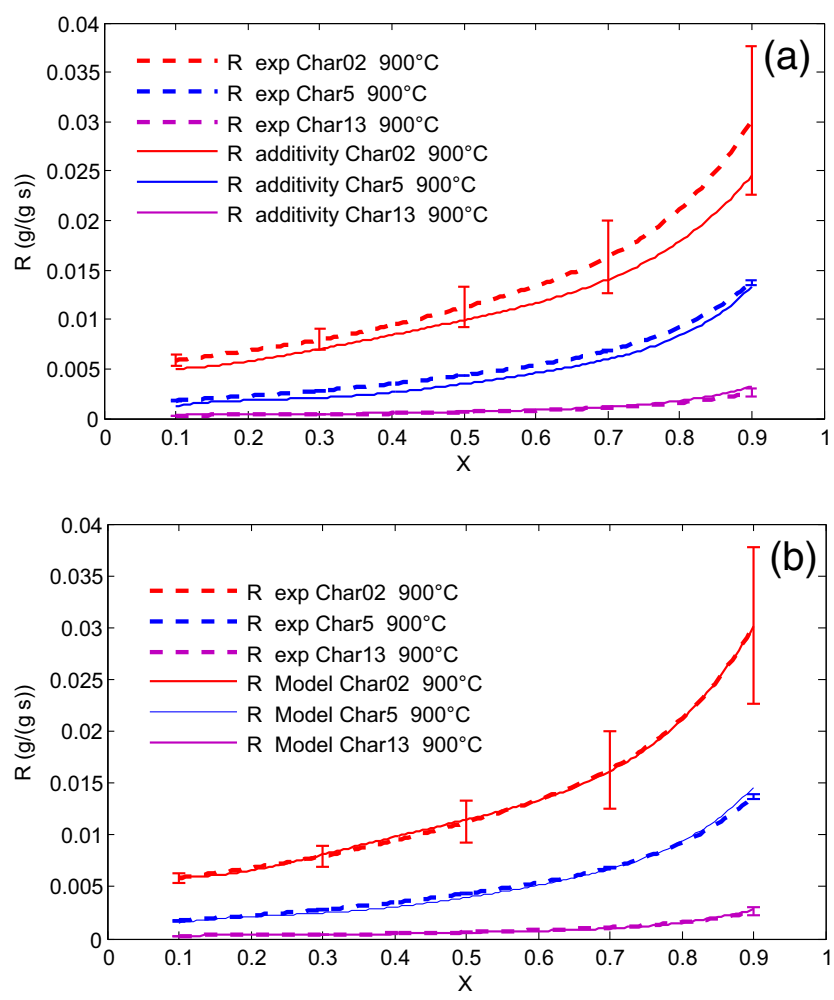

Fig. 11. Experimental char gasification reactivity in $20 \% \mathrm{H}_{2} \mathrm{O}+20 \% \mathrm{CO}_{2}$ at $900{ }^{\circ} \mathrm{C}$ for char02, char5 and char13 and modelling results (a) additivity model and (b) best fit.
At $1000^{\circ} \mathrm{C}$, the situation is a bit different as only values of $\alpha$ below 0.2 and beta between 1.1 and 1.5 allow to correctly describe the exper imental reactivity without being out of the standard deviation zone in the conversion level range of 0 to 0.4 . At $1100{ }^{\circ} \mathrm{C}, \alpha$ is found to be in the range of 0.81 .1 with $\beta$ in the range of 0 to 0.48 for the modelled re activity to be in the standard deviation zone for levels of conversion be tween 0.1 and 0.3 . Beyond $X=0.3$, all possible combination of $\alpha$ and $\beta$ give correct predictions. These results indicate that it is not possible to make a statement on the gasification mechanism in mixed atmosphere gasification at $800{ }^{\circ} \mathrm{C}$ and $900{ }^{\circ} \mathrm{C}$ as wide ranges of $\alpha$ and $\beta$ are found to reproduce the experimental results. At $1000^{\circ} \mathrm{C}$ and $1100{ }^{\circ} \mathrm{C}$, the situa tion is a bit different as only particular $\alpha$ and $\beta$ values give correct rep resentations of the reactivity, yet they are limited to the defined conversion ranges out of which it is not possible to define which gas is the most reactive with char. In the literature, as seen in the Introduction section of the present paper, many studies state on the gas ification mechanism as it is a passive cooperation from the observation that there is an additive law representing well the reactivity in mixed at mosphere. This statement has to be taken with caution regarding the re sults of the present studies. What appears to be an additive law may in fact be a more complex mechanism involving competition and synergy effects that result in an additive like mechanism.

3.2.2. Effect of the char particle size on the mixed atmosphere gasification

Fig. 11 shows the char reactivity at a temperature of $900{ }^{\circ} \mathrm{C}$, in a mixed atmosphere of $20 \% \mathrm{H}_{2} \mathrm{O}+20 \% \mathrm{CO}_{2}$ for the char02, char5 and char13 samples. Decrease in reactivity with size is related to mass trans fer limitations as discussed previously. In Fig. 11a, we plotted the exper imental reactivities along with an additivity model for which $\alpha=\beta=1$. As it can be seen in the figure, the additivity model represents quite fair ly the char reactivity in mixed atmospheres of $\mathrm{H}_{2} \mathrm{O}$ and $\mathrm{CO}_{2}$. For high dif fusional limitations (char13) as well as for quite low ones (char02), the mixed atmosphere char reactivity in $20 \% \mathrm{H}_{2} \mathrm{O}+20 \% \mathrm{CO}_{2}$ at $900{ }^{\circ} \mathrm{C}$ can be fairly considered as the sum of the individual reactivity contributions. The best fit modelling results give values for $\alpha$ and $\beta$ different from 1 . The values of $\alpha$ and $\beta$ equal respectively 1.61 and 0.1 for char02, 1.58 and 0.1 for char5 and 0.9 and 0.8 for char 13 . The tow gases are likely

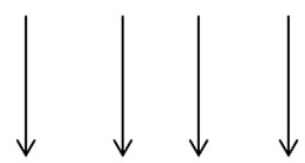

$\mathrm{CO}_{2}, \mathrm{H}_{2} \mathrm{O}$

$C_{e n v}$

h2

h1

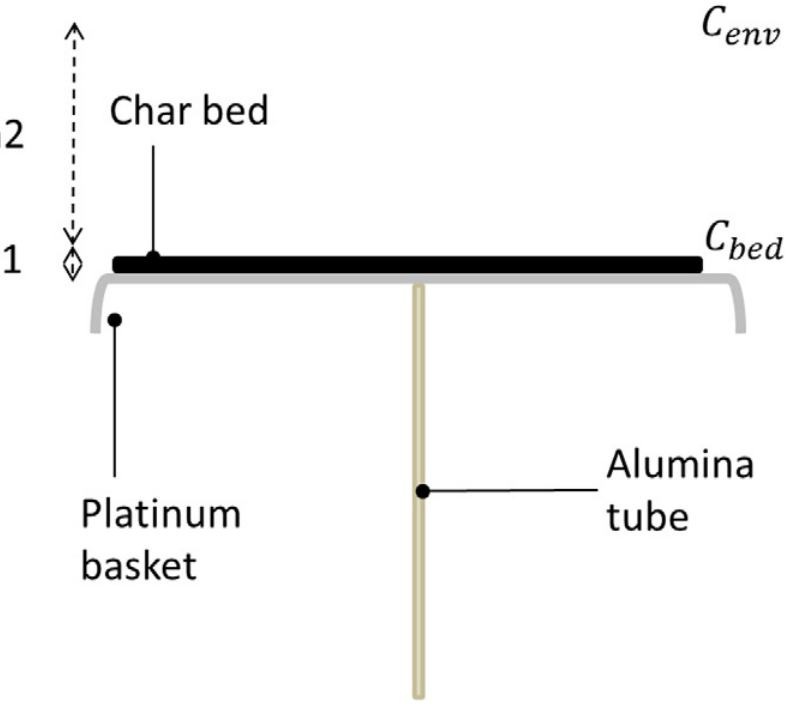

Fig. 12. A schematic representation of the char04 gasification at $900{ }^{\circ} \mathrm{C}$ with $\mathrm{H}_{2} \mathrm{O}$ or $\mathrm{CO}_{2}$. 
competing for the biggest chars while $\mathrm{H}_{2} \mathrm{O}$ seems to have an enhanced activity in the presence of $\mathrm{CO}_{2}$ for the char02 and char5 samples. How ever, there exist a wide range of $\alpha / \beta$ combinations that ensure a good representation of the experimental results, so that we cannot state the contribution of each reaction to the char gasification. This modelling ap proach allows only to calculate the reactivity in the mixed atmosphere but not to understand the gasification mechanism. Another approach is needed to go deeper into this issue.

\section{Conclusion}

The objective of the present work was to evaluate the extent of dif fusional limitations when varying the temperature and char particle size and also to shed light on the influence of temperature and char par ticle size on the multi component gasification reaction with $\mathrm{CO}_{2}$ and $\mathrm{H}_{2} \mathrm{O}$.

Adopting an effectiveness factor approach, we quantified the extent of the internal diffusional limitations in a large char particle size ranging from $0.04 \mathrm{~mm}$ to $13 \mathrm{~mm}$ for both $\mathrm{H}_{2} \mathrm{O}$ and $\mathrm{CO}_{2}$ gasification reactions. We found a similar effectiveness factor evolution with particle size for both reactions. The diffusion reaction competition for both gasification reac tions was nearly the same for both molecules. However, $\mathrm{H}_{2} \mathrm{O}$ was found to have an almost twice higher reactivity and diffusivity than $\mathrm{CO}_{2}$ explaining the equivalence of the diffusion reaction competition. At $900{ }^{\circ} \mathrm{C}$, the char gasification $\mathrm{H}_{2} \mathrm{O}$ or $\mathrm{CO}_{2}$ would be performed in the chemical regime for char particles of $0.04 \mathrm{~mm}$ and below.

In the second part, we assessed the effect of temperature and parti cle size on mixed atmosphere gasification. The char02 reactivity in the mixed atmosphere of $\mathrm{H}_{2} \mathrm{O}$ and $\mathrm{CO}_{2}$ was nearly equal to the sum of the individual reactivity at $800{ }^{\circ} \mathrm{C}$, a little bit higher at $900{ }^{\circ} \mathrm{C}$ and lower than that at $1000^{\circ} \mathrm{C}$ and $1100^{\circ} \mathrm{C}$ for $0.2 \mathrm{~mm}$ sized char particles. High diffusional limitations at 1000 and $1100{ }^{\circ} \mathrm{C}$ caused the gasification reac tion mechanism to shift from reaction on separate active sites to compe tition between the two gases to access the char active sites.

Despite the reactivity in mixed atmosphere being well represented by a linear combination of the two individual reactivities, it is not
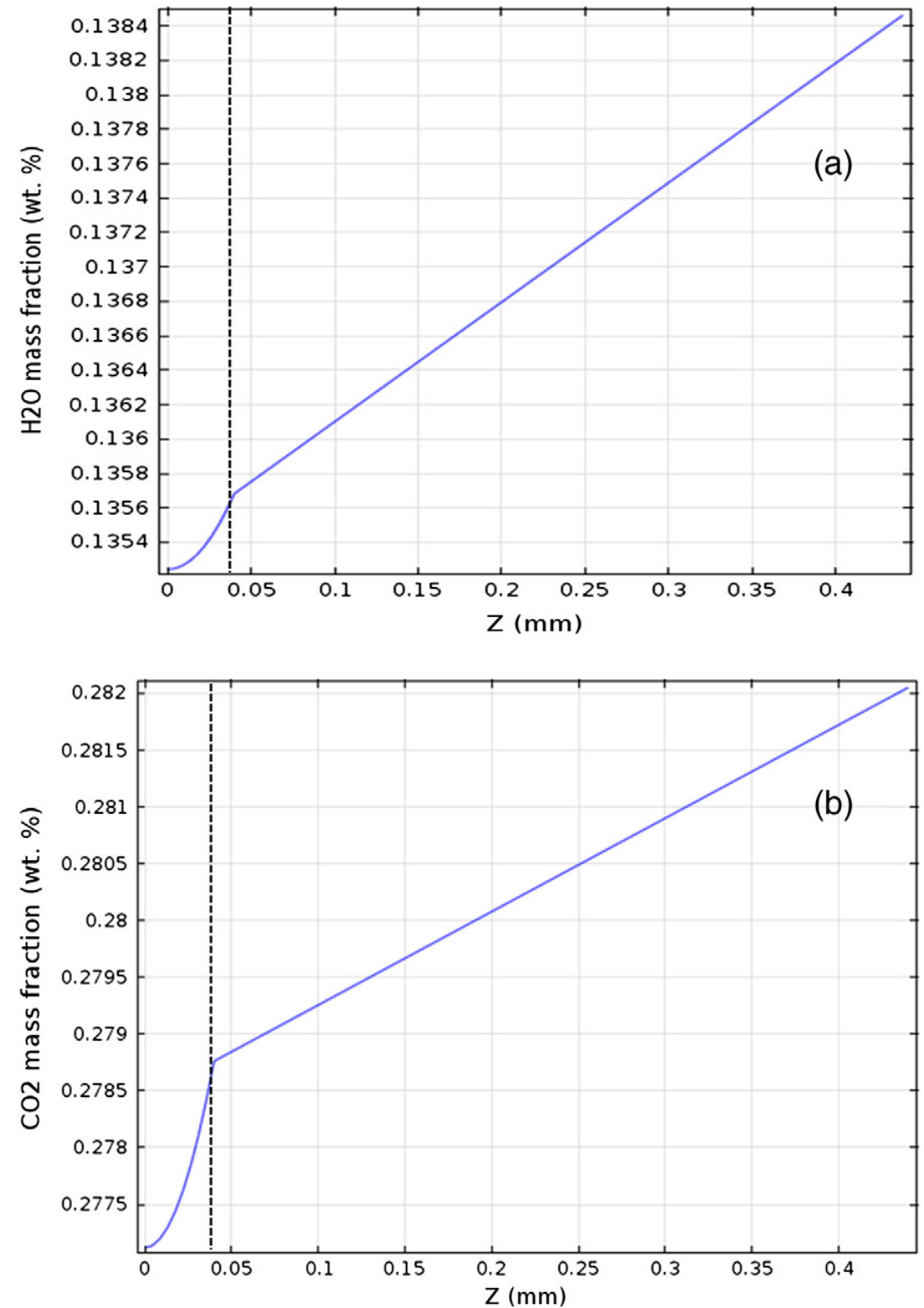

Fig. 13. $\mathrm{H}_{2} \mathrm{O}$ (a) and $\mathrm{CO}_{2}$ (b) mass fractions in the surrounding and in the char bed. The dashed black line represents the interface between the char bed surface and the surroundings. 
possible to state on the gasification mechanism due to the wide range of $\alpha$ and $\beta$ combinations that allow to reproduce correctly the char reactiv ity, especially at $800{ }^{\circ} \mathrm{C}$ and $900{ }^{\circ} \mathrm{C}$. Similar conclusions were drawn when varying the particle size as it was not possible to determine the gasification mechanism due to various linear coefficient combinations allowing to correctly model the char reactivity.

To the best of the authors' knowledge, these results on biomass char gasification in complex atmospheres are quite new in the literature. Fur ther investigations are needed, especially concerning the char property evolution along the gasification reactions in $\mathrm{H}_{2} \mathrm{O}, \mathrm{CO}_{2}$ and in $\mathrm{CO}_{2}+\mathrm{H}_{2} \mathrm{O}$ in order to understand the reaction mechanisms. This issue will be tack led in future works.

\section{Acknowledgements}

The authors acknowledge the national research agency ANR France ( ANR 10 BIOE 0002) for its financial support in the RECO2 project. They also wish to express their appreciation for Bernard Auduc for his technical support.

\section{Appendix A}

To check the accuracy of the thermogravimetric data obtained at $900{ }^{\circ} \mathrm{C}$, so that the reaction rate is effectively determined for a reactant concentration of $20 \%$ at the char bed surface, we considered a monodimensional diffusion model involving the external diffusion of the reactant gas $\left(\mathrm{H}_{2} \mathrm{O}\right.$ or $\left.\mathrm{CO}_{2}\right)$ from the environment where the molar concentration is $C_{e n v}=20 \%$ to the char bed where the concentration is $C_{b e d}$, and a diffusion within the char bed with a volumetric reaction term (source term) corresponding to the carbon consumption. The study was applied to the case of the $0.04 \mathrm{~mm}$ char particles for which the reaction rate is the highest compared to the other bigger particles. The source term is determined from the experimental reactivity obtain ed at $\mathrm{X}=0.5$. The external diffusion height $(\mathrm{h} 2=0.4 \mathrm{~mm}$ ) is fixed to 10 times that of the internal diffusion inside the char bed $(\mathrm{h} 1=0.04 \mathrm{~mm})$.

A schematic representation of the gasification reaction in is shown in Fig. 12.

Fick's second law in a steady state regime gives:

$\nabla \quad J_{i}=R_{i}$.

The suffix " $\mathrm{i}$ " designates the gas species involved in the gasification reaction $\left(\mathrm{CO}_{2}, \mathrm{CO}\right.$ and $\mathrm{N}_{2}$ in the Boudouard reaction, and $\mathrm{H}_{2} \mathrm{O}, \mathrm{CO}, \mathrm{H}_{2}$ and $\mathrm{N}_{2}$ in the steam gasification reaction).

$J_{i}\left(\mathrm{~kg} / \mathrm{m}^{2} \cdot \mathrm{s}\right)$ is the diffusive flux calculated by Fick's law:

$J_{i}=\rho D_{i} \nabla \omega_{i}$

where:

- rho: the total gas density $\left(\mathrm{kg} / \mathrm{m}^{3}\right)$

- $D_{i}$ : molecular diffusion coefficient $\left(\mathrm{m}^{2} / \mathrm{s}\right)$. The effective diffusion coef

ficient in the char bed is corrected by the ratio $\frac{\varepsilon}{\tau}$.

- $\omega_{i}$ : gas specie "i" mass fraction

$R_{i}\left(\mathrm{~kg} / \mathrm{m}^{3} \cdot \mathrm{s}\right)$ is the source term determined from the experimental carbon consumption in the char bed at $\mathrm{X}=0.5$. Stoichiometric consid erations allow calculating the source term for each gas species consider ing the two chemical reaction of Boudouard and steam gasification.

Boudouard reaction : $\mathrm{C}+\mathrm{CO}_{2} \rightarrow 2 \mathrm{CO}$

Steam gasification : $\mathrm{C}+\mathrm{H}_{2} \mathrm{O} \rightarrow \mathrm{CO}+\mathrm{H}_{2}$.

The modelling results are shown in Fig. 13. It can be seen in this fig ure that the gas concentration at the bed surface is very close to that in the surroundings. A quite small decrease is found, and thus external dif fusional limitations can be assumed to be negligible.

\section{References}

[1] P. Basu, Biomass Gasification and Pyrolysis: Practical Design and Theory, Elsevier, 2010.

[2] C. Di Blasi, Combustion and gasification rates of lignocellulosic chars, Prog. Energy Combust. Sci. 35 (2009) 121-140 (Apr.).

[3] M.J. Groneveld, V. S. W.P.M., Gasification of char particles with $\mathrm{CO}_{2}$ and $\mathrm{H}_{2} \mathrm{O}$, Chem. Eng. Sci. 35 (1980) 307-313.

[4] M. Barrio, Experimental Investigation of Small-scale Gasification of Biomass(PhD Thesis) The Norwegian University of Science and Technology, 2002.

[5] J.P. Tagutchu, Gazéification du charbon de plaquettes forestières: particule isolée et lit fixe continu( $\mathrm{PhD}$ thesis) Université de perpignan, 2008.

[6] D. Roberts, D. Harris, Char gasification in mixtures of $\mathrm{CO}_{2}$ and $\mathrm{H}_{2} \mathrm{O}$ : competition and inhibition, Fuel 86 (2007) 2672-2678 (Dec.)

[7] H.C. Butterman, M.J. Castaldi, Influence of $\mathrm{CO}_{2}$ injection on biomass gasification, Society (2007) 8875-8886.

[8] H.C. Butterman, M.J. Castaldi, $\mathrm{CO}_{2}$ as a carbon neutral fuel source via enhanced biomass gasification, Environ. Sci. Technol. 43 (2009) 9030-9037 (Dec.).

[9] S. Nilsson, A. Gómez-Barea, P. Ollero, Gasification of char from dried sewage sludge in fluidized bed: reaction rate in mixtures of $\mathrm{CO}_{2}$ and $\mathrm{H}_{2} \mathrm{O}$, Fuel 105 (2013) 764-768 (Mar.).

10] S. Nilsson, A. Gómez-Barea, D. Fuentes-Cano, M. Campoy, Gasification kinetics of char from olive tree pruning in fluidized bed, Fuel 125 (2014) 192-199 (June).

[11] C. Guizani, F. Escudero Sanz, S. Salvador, The gasification reactivity of high-heatingrate chars in single and mixed atmospheres of $\mathrm{H}_{2} \mathrm{O}$ and $\mathrm{CO}_{2}$, Fuel 108 (2013) 812-823 (June).

[12] T. Liliedahl, K. Sjöström, Modelling of char-gas reaction kinetics, Fuel 76 (1) (1997) 29-37.

[13] R.C. Everson, H.W. Neomagus, H. Kasaini, D. Njapha, Reaction kinetics of pulverized coal-chars derived from inertinite-rich coal discards: gasification with carbon dioxide and steam, Fuel 85 (2006) 1076-1082 (May).

[14] Z. Huang, J. Zhang, Y. Zhao, H. Zhang, G. Yue, T. Suda, M. Narukawa, Kinetic studies of char gasification by steam and $\mathrm{CO}_{2}$ in the presence of $\mathrm{H}_{2}$ and $\mathrm{CO}$, Fuel Process. Technol. 91 (2010) 843-847 (Aug.).

[15] H.-L. Tay, S. Kajitani, S. Zhang, C.-Z. Li, Effects of gasifying agent on the evolution of char structure during the gasification of Victorian brown coal, Fuel 103 (2013) 22-28. http://dx.doi.org/10.1016/j.fuel.2011.02.044 (ISSN 0016-2361).

[16] C. Chen, J. Wang, W. Liu, S. Zhang, J. Yin, G. Luo, H. Yao, Effect of pyrolysis conditions on the char gasification with mixtures of $\mathrm{CO}_{2}$ and $\mathrm{H}_{2} \mathrm{O}$, Proc. Combust. Inst. 34 (2013) 2453-2460 (Jan.)

[17] S. Umemoto, S. Kajitani, S. Hara, Modeling of coal char gasification in coexistence of $\mathrm{CO}_{2}$ and $\mathrm{H}_{2} \mathrm{O}$ considering sharing of active sites, Fuel 103 (2013) 14-21 (Jan.).

[18] Y. Bai, Y. Wang, S. Zhu, L. Yan, F. Li, K. Xie, Synergistic effect between $\mathrm{CO}_{2}$ and $\mathrm{H}_{2} \mathrm{O}$ on reactivity during coal chars gasification, Fuel (2014) 1-7 (Feb.).

[19] A. Gómez-Barea, P. Ollero, C. Fernández-Baco, Diffusional effects in $\mathrm{CO}_{2}$ gasification experiments with single biomass char particles. 1. Experimental investigation, Energy Fuel 20 (2006) 2202-2210 (Sept.).

[20] F. Mermoud, F. Golfier, S. Salvador, L. Vandesteene, J. Dirion, Experimental and numerical study of steam gasification of a single charcoal particle, Combust. Flame 145 (2006) 59-79 (Apr.)

[21] F. Mermoud, Gazéification de charbon de bois à la vapeur d' eau: de la particule isolée au lit fixe continu(PhD thesis) INPT Toulouse2006.

[22] L. Van de steene, J. Tagutchou, F. Escudero Sanz, S. Salvador, Gasification of woodchip particles: experimental and numerical study of $\operatorname{charH}_{2} \mathrm{O}$, charCO charO $_{2}$ reactions, Chem. Eng. Sci. 66 (2011) 4499-4509 (Oct.).

[23] W. Klose, M. Wolki, On the intrinsic reaction rate of biomass char gasification with carbon dioxide and steam, Fuel 84 (2005) 885-892 (May).

[24] T. Pattanotai, H. Watanabe, K. Okazaki, Experimental investigation of intraparticle secondary reactions of tar during wood pyrolysis, Fuel 104 (2013) 468-475 (Feb.)

[25] U. Henriksen, C. Hindsgaul, B.R. Ovale, J. Fjellerup, A.D. Jensen, Investigation of the anisotropic behavior of wood char particles during gasification, Energy Fuel 20 (2006) 2233-2238 (Sept.).

[26] F. Mermoud, S. Salvador, L. Vandesteene, F. Golfier, Influence of the pyrolysis heating rate on the steam gasification rate of large wood char particles, Fuel 85 (2006) 1473-1482 (July).

[27] A. Sadezky, H. Muckenhuber, H. Grothe, R. Niessner, U. Pöschl, Raman microspectroscopy of soot and related carbonaceous materials: spectral analysis and structural information, Carbon 43 (2005) 1731-1742 (July).

[28] P. Ollero, A. Serrera, R. Arjona, S. Alcantarilla, The $\mathrm{CO}_{2}$ gasification kinetics of olive residue, Biomass Bioenergy 24 (2003) 151-161 (Feb.).

[29] M. Barrio, B. Gø bel, H. Risnes, U. Henriksen, J.E. Hustad, N.K. Allé, D.-K. Lyngby, Steam gasification of wood char and the effect of hydrogen inhibition on the chemical kinetics, in: A.V. Bridgwater (Ed.)Progress in Thermochemical Biomass Conversion, 2001, pp. 32-46.

30] F.A. Tanjung, Gasification of single wood particles in $\mathrm{CO}_{2}$, Fuel 67 (1988) 666-672.

[31] K. Umeki, S.-A. Roh, T.-J. Min, T. Namioka, K. Yoshikawa, A simple expression for the apparent reaction rate of large wood char gasification with steam, Bioresour. Technol. 101 (2010) 4187-4192 (June).

[32] A. Gómez-Barea, Modelling of Diffusional Effects During Gasification of Biomass Char Particles in Fluidised-bed(PhD Thesis) University of Seville, 2006.

[33] W. Huo, Z. Zhou, F. Wang, Y. Wang, G. Yu, Experimental study of pore diffusion effect on char gasification with $\mathrm{CO}_{2}$ and steam, Fuel 131 (2014) 59-65 (Sept.). 
[34] T. Mani, N. Mahinpey, P. Murugan, Reaction kinetics and mass transfer studies of biomass char gasification with $\mathrm{CO}_{2}$, Chem. Eng. Sci. 66 (2011) 36-41 (Jan.).

[35] E.W. Thiele, Relation between catalytic activity and size of particle, Ind. Eng. Chem. 31 (7) (1939) 916-920.

[36] A. Bliek, J. Lont, W. van Swaaij, Gasification of coal-derived chars in synthesis gas mixtures under intraparticle mass-transfer-controlled conditions, Chem. Eng. Sci. 41 (1986) 1895-1909 (Jan.).

[37] A. Gomezbarea, P. Ollero, A. Villanueva, Diffusional effects in $\mathrm{CO}_{2}$ gasification experiments with single biomass char particles. 2 . Theoretical predictions, Energy Fuel 2 (2006) 2211-2222.

[38] S. Nilsson, A. Gómez-Barea, D.F. Cano, Gasification reactivity of char from dried sewage sludge in a fluidized bed, Fuel 92 (2012) 346-353 (Feb.)

[39] S. Valin, M. Grateau, S. Thiery, G. Gauthier, F. Defoort, T. Melkior, Influence of atmosphere $\left(\mathrm{N}_{2} / \mathrm{CO}_{2} / \mathrm{H}_{2} \mathrm{O}\right)$ on wood centimetre-scale particle devolatilisation at $800{ }^{\circ} \mathrm{C}$, Fuel 139 (2015) 584-593 (Jan.).
[40] C. Hognon, C. Dupont, M. Grateau, F. Delrue, Comparison of Steam Gasification Reactivity of Algal and Lignocellulosic Biomass: Influence of Inorganic Elements, Bioresource Technology, 2014. (May).

[41] B. Feng, Structural ordering of coal char during heat treatment and its impact on reactivity, Carbon 40 (2002) 481-496 (Apr.).

[42] A. Zolin, A. Jensen, P.A. Jensen, F. Frandsen, K. Dam-Johansen, The influence of inorganic materials on the thermal deactivation of fuel chars, Energy Fuel 15 (2001) 1110-1122 (Sept.).

[43] D.M. Keown, G. Favas, J.-I. Hayashi, C.-Z. li, Volatilisation of alkali and alkaline earth metallic species during the pyrolysis of biomass: differences between sugar cane bagasse and cane trash, Bioresour. Technol. 96 (2005) 1570-1577 (Sept.).

[44] D.G. Roberts, D.J. Harris, Char gasification kinetics in mixtures of $\mathrm{CO}_{2}$ and $\mathrm{H}_{2} \mathrm{O}$ : the role of partial pressure in determining the extent of competitive inhibition, Energy Fuel 28 (2014) 7643-7648. 